\title{
Ireland and the Waterloo campaign of 1815
}

\section{Peter Molloy}

\begin{abstract}
Ireland's experience of the Waterloo campaign has been consistently underexplored, despite the degree of attention paid to the campaign by historians. This paper shows that that experience was far more significant and multi-faceted than has generally been recognised. Irish people played an important practical role in the events of 1815 . Irish soldiers saw service in their thousands during the campaign, at every rank from private to general. These men represented a comprehensive cross-section of contemporary Ireland, coming from every county on the island and from every kind of socio-economic background. Some Irish soldiers and military units earned distinction for their actions on the battlefield and a number of participants from the country left valuable primary testimony. Civilian Irish women and children were also caught up in events in Belgium. Domestically, Ireland was a centre of activity as hostilities against Napoleon developed and analysis of contemporary media coverage and private correspondence makes it clear that ongoing events on the Continent had a keenly engaged Irish audience. Waterloo also left a distinctive legacy for Ireland and for Irish people. This paper explores all of these issues in detail, providing a thorough examination based on primary sources to address the impact of Waterloo on Ireland, and of the Irish on Waterloo.
\end{abstract}

This paper is a reproduction of an MA thesis submitted for the MA in Military History and Strategic Studies at Maynooth University in 2011 and published online via the Maynooth University Research Archive Library MURAL in 2012.

An adaptation of the thesis was also published as 'Ireland and the Waterloo Campaign' in The Irish Sword Vol. XXX No. 119, Summer 2015 pp.13-58. 


\section{Introduction}

Seven-and-thirty years have elapsed since the day of Waterloo, and yet the memory of it is so rife, and the interest belonging to it so easily revived, and so powerful when awakened, that it requires an effort to detach oneself from it, having once touched it. Ireland is not thought of by foreigners, nor even by Englishmen in general, when speaking of that great battle; and yet, more than a moiety of the army of Wellington throughout his career, and especially at Waterloo, were, like himself, Irish. These latter facts will, I trust, excuse the length I have permitted to myself in dealing with an action that changed the face of Europe. ${ }^{1}$

Despite the passage of almost exactly two centuries, the Waterloo campaign of June 1815 persists as an important historical milestone. The episode proved the final, sanguinary instalment in a prolonged period of European conflict and imbalance which had lasted for more than two and a half decades, since the outbreak of the French Revolution in 1789. Allied victory over Napoleon Bonaparte at Waterloo meant a permanent end to the First French Empire, and ushered in a welcome interlude of relative European stability and prosperity. Events in 1815 also signified a continued rise in influence for other continental powers, most notably Britain and Prussia.

Rather unsurprisingly, a vast quantity of research dealing with various aspects of Waterloo as well as the wider 'Hundred Days' period is already in existence. ${ }^{2}$ Published secondary study has been attempted an almost every conceivable facet of the 1815 campaign: from tomes on uniforms, weapons and tactics to multiple biographies of key commanders and military personalities. This prolonged historiographical focus on Waterloo displays little sign of waning, with at least two new English language works featuring the campaign published in 2010 alone. ${ }^{3}$ Were this not enough, the rapidly approaching bicentenary of Waterloo in 2015 will inevitably act as a spur to focus yet more scrutiny on the military events which played themselves out in Belgium and northern France. When the sheer volume of scholarship on the campaign is considered, then, it is tempting to yield to cynicism and wonder what possible feature could by now remain virgin territory as far as constructive analysis is concerned.

While such an attitude may be understandable, it is also substantially inaccurate. The issue of Ireland's connections to the Waterloo campaign is one which is to date remarkably under-explored. It is true, of course, that specific research has been undertaken on individual personalities with Irish connections; Arthur Wellesley, $1^{\text {st }}$ Duke of Wellington and commander of one of the two Allied armies opposed to Napoleon in June 1815 , being an especially well-known example. ${ }^{4}$ Military units which participated in the campaign and which enjoyed explicit Irish affiliation, like the British army's $27^{\text {th }}$ (Inniskilling) Foot or its sister regiment, the $6^{\text {th }}$ (Inniskilling) Dragoons, have also featured in secondary study. ${ }^{5}$ But an effort at producing a broader assessment of the links between Ireland and Waterloo would appear to remain so far absent. 
That omission is as puzzling as it is regrettable, for a very strong case indeed may be argued as to the significance of those links. As far as practical involvement in the campaign is concerned, Irish soldiers can be argued to have formed a large national bloc in 1815; concentrated overwhelmingly within the British portion of the Duke of Wellington's Anglo-Allied army. These personnel came from all corners of the island, from every possible social background, and fought at Waterloo in almost every arm and capacity from private soldiers to senior commanders. A number of Irish soldiers or units became prominent as a result of their endeavours on the battlefields of 1815 , while some Irishmen left valuable records of their Waterloo experiences in the form of letters and memoirs. Irish civilians were also caught up by events, both as fascinated domestic spectators and also as military dependents present during the campaign itself. And even before battle had actually been joined, Ireland had effectively functioned as a military staging post for the campaign, with a large number of the British units involved in the Hundred Days - not just those few with formal Irish identities - stationed there prior to Waterloo and departing for war from Irish ports like Cobh and Dublin.

Nor did Irish connections cease with the last volleys of musketry in 1815. Waterloo bequeathed a distinctive legacy to the country. The campaign was commemorated and celebrated in Ireland in a variety of fashions, from monuments and place names to tourism, verses and plays. The post-Waterloo experiences of Irish veterans, a number of whom lived to the very end of the nineteenth century, was equally complex, with some going on to later fame or noteworthy military service, while others struggled with economic hardship and physical infirmity.

Ironically, tangible reminder of this fascinating tapestry is easily identifiable in contemporary Ireland. The knowledgeable modern visitor to the island's first city of Dublin can, over the course of a forty minute stroll, take in what amounts to a microcosm of Ireland's Waterloo experience. From O'Connell Bridge, a perfect view can be had of the stonewalled quays on either side of the River Liffey. In the spring and early summer of 1815 , this area was one of the Irish embarkation points echoing to the tramp of marching troops and the bawled orders of noncommissioned officers, as British regiments took ship at the beginning of their journey to Belgium and the Waterloo campaign. An officer of one of those units would later recall its very first casualty of the Hundred Days: an older soldier who tumbled from a gangplank and drowned here in the murky waters of the Liffey. ${ }^{6}$

Walking west takes the traveller past a distinctive cast iron pedestrian bridge; known to generations of Dubliners as the Ha'Penny Bridge but christened the Wellington Bridge at its opening in 1816 to honour the Irish soldier who had so recently helped to defeat Napoleon at Waterloo. Further upstream from the bridge is a section of quayside similarly named for Wellington. Journey's end comes just beyond Heuston Station, Dublin's western railway terminus. Visible to the left is the clock tower of the former Royal Military Hospital at Kilmainham. It was in this institution, founded under King Charles II in 1684, that some of the more fortunate Irish veterans of the campaign passed their twilight years in relative peace and security. Across the Liffey to the right, unmistakable above the trees of the Phoenix Park, towers what is comfortably the largest physical monument in Ireland connected to both Waterloo and the wider Napoleonic Wars - the granite obelisk of the Wellington Testimonial. 
This route arguably takes Ireland's links to Waterloo full term: from the excitement, confusion and tragedy of the campaign itself, to the lasting commemoration and human legacy of 1815. This thesis aims to accomplish a similar journey by presenting two principal arguments. Firstly, that Ireland's practical role in the Waterloo campaign was an important one, and was far broader than the specific elements of Irish involvement which have hitherto received study. Secondly, that Waterloo had a significant longer term influence on the country which encompassed a number of different arenas; from popular acknowledgment and memorialization, to the post-conflict experiences of the Irish soldiers who fought in the campaign.

It has already been observed that literature dealing the Waterloo campaign is incredibly prodigious. Indeed, study of the episode has by this point become almost a genre of its own right within the wider field of military history. Though a case has been advanced as to the specific deficiency within this scholarship that this thesis hopes to contribute to remedying, it is helpful nonetheless to properly establish its relationship to recent historiography.

More modern study of Waterloo has arguably tended toward a significant departure from the relatively chauvinistic and unilateral perspectives on the campaign evident in early assessments like Edward Creasy's The fifteen decisive battles of the world (1851), or in later works by writers like William Fortescue. ${ }^{7}$ An important step away from this narrow approach came with Lord Chalfont's edited work Waterloo: battle of three armies $(1979)^{8}$; which, by providing concurrent Anglo-Allied, French and German interpretations of the campaign, suggested a shift in the focus of Waterloo historiography toward a more inclusive, pan-national perspective. That welcome change in emphasis has continued in recent publications. The Waterloo companion (2001) ${ }^{9}$, for example, Mark Adkin's admirable recent reference work on the campaign, makes a firm effort at providing a multilateral assessment of events in 1815; an objective similarly displayed in modern histories like Andrew Uffindel and Michael Corum's On the fields of glory (1996) and Alessandro Barbero's The battle (2005). ${ }^{10}$ British historian Peter Hofschröer has succeeded over the past decade and a half in shedding necessary light on the role played by smaller national contingents at Waterloo, as well as providing a revised perspective on Prussia's role in the campaign. ${ }^{11}$ Collectively, it may be argued that this new pattern of assessment amounts to an appreciation that the legacy of Waterloo is no more a British or French national property than it is a German or Dutch possession; but instead represents something of communal significance to Europe as a whole.

Significant expression of this more recent interpretation of Waterloo is likely to occur in less than four years' time, with the bicentenary of the 1815 campaign. For obvious reasons, international preoccupations on the occasion of the campaign's centenary in 1915 prohibited any sort of unified European commemoration. In any case, it is probable that even without the baleful interruption of the First World War, the kind of nationalistic perspectives mentioned already would have precluded much in the way of a multinational reflection on the events of 1815 .

2015 promises to mark an altogether different instalment in the legacy of Waterloo; one which will arguably be a fitting reflection of the truly pan-European nature of that event. 'Waterloo 200', as an example, the official British committee charged with overseeing that country's preparations for the bicentenary, goes to 
lengths on its website to emphasise that multinational perspective: noting that the campaign was a 'milestone in European history' and describing its efforts as a 'unique international project', which will involve 'people from many nations' ${ }^{12}$

It is from this contemporary climate of revised, multilateral viewpoints on the Waterloo campaign, therefore, that this thesis derives its primary influence. An attempt to examine, even at a necessarily introductory level, the connections which exist between Ireland and that event would appear to be entirely in step with this.

\section{PART 1. THE HUNDRED DAYS AND THE WATERLOO CAMPAIGN, MARCH-JULY 1815}

Even for an experienced soldier, the sight was jarring. It was the early morning of Monday 19 June 1815, and Captain Harry Ross-Lewin was picking his way carefully across the fresh carnage of a battlefield outside the southern Belgian village of Waterloo. The infantry officer from County Clare was no stranger to bloodshed, having served with the British army in a score of engagements from the West Indies to Spain and Portugal. What had occurred here on the previous day, however, had been utterly shattering in its intensity and violence:

The mangled bodies of men and horses, broken gun-carriages, caps, helmets, cuirasses, arms, drums, harness, accoutrements, pieces of battered uniforms, knapsacks, letters, and cards, that were strewed abundantly in all directions, and the crops levelled by the trampling of infantry and cavalry in the strife, plainly marked the extent of the field, and gave undeniable evidence of the fury of the conflict that had raged there. ${ }^{13}$

It is certainly not desired to further clutter already crowded historiographical terrain by offering a potted history of the Waterloo campaign. However, it is essential at this point to provide some overview of the military and political developments which took place in 1815 , in order to properly contextualise Ireland's role in this period.

It was deeply ironic that at the beginning of March that year - just over three months before Captain Ross-Lewin made his unhappy survey of battle's aftermath at Waterloo - Europe had been enjoying an unprecedented period of peace and prosperity. The state of turmoil which had plagued the continent since the beginning of the French Revolution in $\mathbf{1 7 8 9}$ had come to a seemingly definitive end the previous spring, when the French Emperor Napoleon Bonaparte had finally been compelled by force of arms to abdicate in favour of a restored Bourbon monarchy. The erstwhile French ruler was now ensconced in comparatively comfortable exile on the Mediterranean island of Elba. In the Austrian capital Vienna, representatives of Europe's major powers were convened in order to draft the future map of the continent in this new, post-Revolutionary and post-Napoleonic world.

This relatively satisfactory state of affairs came to a dramatic halt on 7 March 1815, when word reached Vienna's assembled dignitaries that the apparently unthinkable had occurred. Having slipped away from Elba, Napoleon had landed in southern France at the head of only a few hundred followers. ${ }^{14}$ What might initially have struck the ambassadors and diplomats gathered in the Austrian city as being a faintly ridiculous stunt quickly took on a much more serious cast. Napoleon progressed rapidly through France without meeting serious resistance, and on 20 March made a triumphal entrance into Paris. ${ }^{15}$ The Bourbon monarch 
King Louis XVIII had fled the capital before him, after less than a year on the throne of France.

The response of Europe's great powers was unequivocal. Publicly declaring Napoleon an outlaw, Britain, Prussia, Austria and Russia each pledged to field armies of 150,000 men as soon as was possible; with the express intention of invading France and ejecting the returned Emperor. ${ }^{16}$ It would take time for the latter two nations to mobilise their forces, though, and so the immediate threat to Napoleon would be posed by two Allied armies which began to assemble in neighbouring Belgium. A Prussian force of approximately 130,000 soldiers under Field Marshal Gebhard von Blücher would operate in conjunction with a joint British, DutchBelgian and German army, some 112,000 men strong, led by the experienced British commander Field Marshal Arthur Wellesley, Duke of Wellington.

But it was Napoleon who moved first. Hoping by pre-emptive attack to separate the two enemy forces in Belgium and thus defeat each in detail, he struck across the Franco-Belgian border at the head of the 123,000-man ${ }^{17}$ Armée du Nord on 15 June. The short but monumental Waterloo campaign had begun. On 16 June, two distinct battles at Ligny and Quatre Bras marked the first major clashes of the campaign. At Ligny, Blücher's army was badly mauled - though not comprehensively defeated - by Napoleon; the tough seventy two year old Prussian commander himself surviving being unhorsed and ridden over by French cavalry. ${ }^{18}$ Further to the west, around the crossroads of Quatre Bras, Wellington fought a sharp but inconclusive engagement against Napoleon's deputy Marshal Michel Ney. It would be another two days before the decisive episode of the campaign took place.

After an intervening day for all three armies of marching and countermarching across the Belgian countryside, Wellington's Anglo-Allied force had taken up defensive positions along the ridge of Mont St Jean, which ran east to west outside the village of Waterloo, some $12 \mathrm{~km}$ south of Brussels. Facing it on the morning of Sunday 18 June 1815 was the greater part of the Armée du Nord, under Napoleon's personal command. The battle which ensued among the muddy crop fields and farm buildings of the area lasted for around nine hours. At its close, some 54,000 soldiers of all nationalities had become casualties. With Wellington's battered army having succeeded - just - in withstanding repeated French assaults throughout the day, the timely arrival of Blücher's Prussians on the eastern flank of the battlefield finally tipped the tactical balance in favour of the Allies. By nightfall, Napoleon's last, spectacular throw of the dice was effectively over.

On 22 June, the French leader abdicated at Paris for the second and final time, with Allied troops entering the city on 4 July ahead of a second Bourbon restoration. ${ }^{19}$ Napoleon would ultimately be exiled to the Atlantic island of St Helena, where he died in 1821. It was, quite genuinely, the end of an era.

\section{PART 2. IRELAND AND THE OUTBREAK OF HOSTILITIES}

Weeks before the first advance French cavalry patrols clattered across the border with Belgium at dawn on 15 June $1815^{20}$, the effects of Napoleon's incredible return to power were already being keenly felt within Ireland. The news was widely discussed and referenced, and the country was also greatly affected on a practical level by Britain's preparations for war. 
Developments in Europe quickly grew to dominate Irish public discourse; an April editorial in one newspaper summing up the 'extraordinary events that are passing before us'.$^{21}$ Throughout the spring and early summer of 1815 , newspapers and journals across Ireland avidly documented all scraps of political or military information from the Continent, however grounded in truth or otherwise they might actually be. At the beginning of May, for example, the Freeman's Journal drew its readers' attention to the alarming suggestion that Napoleon might already have quit Paris for the French frontiers in order to commence military operations against the Allies. ${ }^{22}$ Amongst numerous other snippets of dubious intelligence in the same edition was the sensationalistic - and completely spurious - claim that two Belgian regiments that had recently sought to desert to the French had instead been 'cut down in the attempt by British troops' ${ }^{23}$

Private Irish correspondence also reflected ongoing events. Remarkably, the very moment of Napoleon's departure from Elba had been witnessed by an Irish traveller, James Grattan. A son of Henry Grattan of Irish Parliament fame, Grattan had journeyed to Elba from Italy in late February 1815; hoping from a sense of curiosity to obtain an audience with Napoleon. In the event, the Irishman got much more than he had bargained for. 'You may suppose I have had an anxious and unpleasant time of it', he wrote to a relative immediately afterwards:

I was landed on the island on Friday last. No person knew of it [the plot to leave Elba] until Sunday evening. He [Napoleon] forbid any person quitting the island for 4 days, then I was left prisoner. It is an anxious moment. Napoleon's troops consist of 1,100 men, some artillery and provisions for 6 days. ${ }^{24}$

A great deal of the initial impact of this international crisis on Ireland hinged around the activities of the British military, as planning for war got underway. The apparent coming of peace with Napoleon's first abdication in 1814 had resulted in an extensive redeployment of British land forces worldwide, and Ireland had been significantly affected by this.

For the duration of the Napoleonic Wars, Britain's principal theatre of land operations against France had been the Peninsular War (1808-14), fought across Portugal, Spain and ultimately southern France. There, an expeditionary force had been commanded with considerable success for most of this period by the same Duke of Wellington who would now be charged with leading a new Allied army against Napoleon himself. With the conclusion of hostilities against France, a number of Wellington's experienced regiments had been dispatched without delay to North America, where Britain was still engaged in the muddled War of 1812 (1812-15) against the United States ${ }^{25}$, while others were dispatched to different locations worldwide on garrison duty. The bulk of the remainder had returned to home stations across the British Isles during the spring, summer and autumn of 1814; a significant number to Ireland. Many of these units would participate in the Waterloo campaign the following year.

There were sensible practical reasons for maintaining large numbers of regular troops in Ireland in this manner. For one thing, the country had experienced over the previous two decades one major and one minor incident of rebellion against Crown rule; in 1798 and 1803 respectively. A strong military establishment provided a measure of security against any future occurrences of this sort. With its 
multitude of ports and harbours and its access to shipping routes to Europe, North America and elsewhere, Ireland had also always been well situated to facilitate the strategic movements of British forces around the world.

The enthusiasm of some non-Irish soldiers for a posting to the country during this period had varied widely. In a letter to family, Welshman Major Edwin Griffith of the $15^{\text {th }}$ Hussars was distinctly nonplussed: 'I don't know whether to be glad or sorry at going to the land of potatoes' ${ }^{26}$ Others found Ireland considerably more to their satisfaction. Scottish Peninsula veteran Private James Gunn was effusive in his praise for both the people and the surroundings of the 'blessed city of Kilkenny', where his battalion was quartered in 1814-15. ${ }^{27}$

A priority for nearly all of the Peninsula regiments stationed in Ireland during this period was recruitment; depleted as most were after years of active campaigning. A number of Irish recruits who would go on to fight with the British army during the Waterloo campaign joined the colours at this stage. Although it is very difficult, if not impossible, to gain a total figure for Irish enlistments during these specific months; it is still instructive to examine some individual cases.

County Kilkenny native David Carroll was typical. Though possessing a trade, as a tailor or tailor's apprentice, twenty year old Carroll nevertheless chose to enlist with the kilted $42^{\text {nd }}$ Highlanders - the famous 'Black Watch' - at his home city of Kilkenny in November $1814 .{ }^{28}$ Eighteen year old County Cavan man John Dignan was another example. He joined the $27^{\text {th }}$ Foot at the very beginning of May 1815 , barely a month and a half before experiencing a dreadful baptism of fire at Waterloo. ${ }^{29}$ Equally new to military life during the campaign was another eighteen year old, labourer Denis Buckley of Blarney, County Cork, who was inducted into the $1^{\text {st }}$ Foot by a Sergeant Heney (or Heaney) at Cork on 5 May 1815. ${ }^{30}$

It is perhaps possible to appreciate one potential point of motivation for Irishmen like Carroll, Dignan or Buckley who joined the army during this interval in hostilities. Garrison towns and cities across Ireland had suddenly filled with returned veterans of the Peninsular War; lean and tanned after so long in foreign climes and inevitably replete with embellished anecdotes of campaigning under Wellington. The large-scale presence of these seasoned soldiers in Ireland and the perceived glamour of their exploits in the Peninsula may very well have played a role in the decisions of some Irishmen to opt for military careers in the months immediately prior to Waterloo. Certainly, one Irish soldier of the period acknowledged the influence that a grizzled veteran had had on his own thought process prior to enlisting: 'From this old blade [a British army veteran of the Egyptian campaign of 1801], I think it was, I acquired that martial ardour that so frequently infects young men in time of war. There was, indeed, no resisting the old pensioner's description of glory'. ${ }^{31}$

For both experienced soldiers and raw recruits, the peacetime routine of garrison life in Ireland was turned utterly on its head from March 1815. Private James Gunn recalled his indignant reaction to word reaching his battalion in Kilkenny that that: 'restless cricket Boney [had] got back to France'. ${ }^{32}$ At once, British units across the country were plunged into a flurry of hasty preparation as it became clear that renewed war against France was highly likely, if not inevitable. 
The unexpected turn of events was not necessarily unwelcome news to all. Ships carrying the $1^{\text {st }}$ Battalion of the $28^{\text {th }}$ Foot had just put out to sea from Cobh in County Cork, bound for Bermuda, when a frigate intercepted the convoy in order to pass on word of what had occurred and order the vessels to return at once to port. For all the uncertainty and danger of a campaign in Europe, the prospect was still felt by most in the infantry battalion to be infinitely preferable to service in distant and fever- ridden Bermuda, as Captain Charles Cadell observed: 'We were quite delighted that our good fortune had not left us, and that we were thus saved a trip across the Atlantic'. ${ }^{33}$ In a letter home to Wales from his quarters at Clonmel, County Tipperary, Major Edwin Griffith jocularly recorded his regiment's satisfaction at being included in the list of British units scheduled to depart Ireland for active service:

Although we feared we should not be present at the opening of the ball in Belgium we flattered ourselves that we were much too accomplished a corps not to receive an invitation. It has accordingly arrived; $\&$ the probability is, that when you receive this we shall be on our march to Cork for embarkation. ${ }^{34}$

Rather more prosaically, the likelihood of war had served to spoil Griffith and his fellow officers' plans for sightseeing: 'Dalrymple \& I had intended to make our first visit to Killarney in May; but this Belgium [sic] party will rather interfere'. ${ }^{35}$

Not all military personnel in Ireland, however, could share the cavalry officer's light-heartedness about events. County Mayo recruit Private Austin Keane, for example, was perhaps an unlikely candidate for a soldier, who had given his civilian trade as 'musician' when he joined the $1^{\text {st }}$ Foot at the age of twenty at Westport in August 1814. War clouds in the spring of 1815 seem to have dampened whatever enthusiasm Keane had originally held for a military life. At the beginning of April that year, he absconded from his battalion, never to be seen by his comrades again. ${ }^{36}$ Another young Irishman, sixteen year old Private Patrick Cummins from County Tipperary, appears to have had similar doubts. Having enlisted into the $32^{\text {nd }}$ Foot at Clonmel in February 1815, he deserted at Cork at the end of April that year as his battalion made its final preparations to take ship. ${ }^{37}$ Writing to his sister from Belfast, a Scottish officer, Captain John Sinclair of the $79^{\text {th }}$ Highlanders, reflected bitterly on the fact that he had entertained: 'a certainty of passing the remainder of my days in retirement, but... how soon are all my fine prospects and flattering hopes blasted, by the escape of that Destroyer of Mankind'. ${ }^{38}$

As the weeks passed, unit after unit bade farewell to their Irish billets and began the journey to Belgium, where the Allied armies of Wellington and Blücher were concentrating. Roads became congested with ponderous and dusty columns of marching troops, horses and guns as the regiments earmarked for service on the Continent moved to their embarkation points. With a prevailing atmosphere of 'hurry and confusion'39, a steady stream of naval transports departed from ports all around Ireland - anchorages in County Cork seeing especially heavy military traffic. At the very beginning of April, for example, a convoy carrying the soldiers of the $14^{\text {th }}$ Light Dragoons and the $1^{\text {st }}$ Battalion of the $52^{\text {nd }}$ Light Infantry departed Cobh for Portsmouth. ${ }^{40}$ Around four weeks later, leaving the same port in a total of twelve transports, it was the turn of the $1^{\text {st }}$ Battalions of the $32^{\text {nd }}$ Foot and the $92^{\text {nd }}$ Highlanders, as well as the $13^{\text {th }}$ Light Dragoons. ${ }^{41}$ Most British units leaving Ireland at this time, like Charles Cadell's battalion of the $28^{\text {th }}$ Foot, travelled first across the 
Irish Sea to English ports like Portsmouth or Deal, before taking ship once again for Belgium.

Some time before the Waterloo campaign had actually commenced, then, Ireland had already been significantly impacted. The astonishing drama and uncertainty of Napoleon's resumption of power in France had provided fodder for public discussion and contemporary reportage, at least some of it distinctly excitable. More immediate again in Ireland during the spring and summer of 1815 were the practical ramifications of British preparations for war. The presence in the country of so many of the British units destined for service in the final campaign against Napoleon led to a period of pitched military activity which extended right across the island. Irish recruitment into the British army had also continued throughout this period.

\section{PART 3. IRISH SOLDIERS AND THE WATERLOO CAMPAIGN}

By any standard, the Waterloo campaign featured an incredibly eclectic cast of nationalities. The belligerents of 1815 spoke in at least four different principal languages ${ }^{42}$ and boasted a dizzying array of geographic origins; from the soldiers of minor German states like Brunswick and Hannover who formed part of Wellington's Anglo-Allied army, to the Polish lancers who fought on one last occasion, far from home, for Napoleon. ${ }^{43}$ Amidst this assemblage, it is perhaps scarcely surprising that some given element of Irish representation occurred. The exact nature and extent of this involvement, however, merits more detailed examination.

This thesis has already identified a number of important links between Ireland and the British military contingent that fought at Waterloo, and expands on this theme below. Before commencing that analysis, though, it is first worth considering the possibility that at least some Irish soldiers might have seen active service during the campaign in capacities other than servants of Britain's King George III.

The idea is not at all as strange as it may appear. It is significant that by the early nineteenth century a tradition of Irish service in Continental European armies was very well established. Of particular potential relevance for Waterloo is the historical existence of a prominent pattern of Irish involvement in the French military; which can be traced (at minimum) to the late seventeenth century and the flight from Ireland of the 'Wild Geese' at the close of the Williamite War of 1689-91. Over the course of the intervening century, Franco-Irish units like the Regiments of Dillon, Walsh and Bulkley had served successive French monarchs ably in conflicts ranging from the War of the Austrian Succession to the American War of Independence. ${ }^{44}$

Revolution in France from 1789 and the dethronement of the Bourbon dynasty weakened this military link, with most of the foreign regiments in French service either disbanded or else dramatically restructured. Despite this, some vestige of Irish connection continued into the Napoleonic era with the creation in France in 1803 of the Légion Irlandaise, or Irish Legion: a force of Irish émigrés originally raised in anticipation of a French invasion of Ireland. ${ }^{45}$ Although that expedition 
never transpired due to French naval defeat at the battle of Trafalgar in 1805, the various components of the Irish Legion did experience significant operational service in other theatres in the years leading up to Napoleon's first abdication in 1814.

Though still being in nominal existence in 1815 , the unit did not take any formal role in the Waterloo campaign.

This does not definitively mean that individual soldiers of Irish heritage were not present within Napoleon's Armée du Nord in other capacities. Intriguingly, two of the French units present at Waterloo, the 87eme and 92eme Régiments $d^{\prime}$ Infanterie de Ligne [line infantry regiments], were theoretically the postRevolution descendants of Ancien Régime Irish regiments (the Regiments of Dillon and Walsh, respectively). ${ }^{46}$ Although the Irish nature of such units by 1815 was almost certainly one of historical style, rather than practical substance, the link is still of interest.

Occasional, if tantalisingly faint, echoes of this possible aspect of Irish involvement may be identified in both primary and secondary sources. In conversation with the English painter Benjamin Robert Haydon after Waterloo, a British cavalryman of the Life Guards named Hodgson claimed to have exchanged sword strokes with an enemy cuirassier [heavy cavalryman] who turned out to be an Irishman in French service. Hodgson declared that he had come off the better in the contest: lopping the Irishman's sword hand off, before spearing him through the throat. ${ }^{47}$

Somewhat more apocryphal is the anonymous note in a 1967 edition of the Irish Sword, journal of the Military History Society of Ireland, which explained an apparent Irish 'Waterloo tradition'. This centered around the alleged battlefield encounter during the campaign of two Irish brothers; one a hussar in Wellington's army, and the other an officer in the French army who had emigrated to France some years previously. ${ }^{48}$ Although it is impossible to verify either incident, neither when considered in full context - is necessarily implausible.

Nor, even, is the suggestion that soldiers of Irish descent may have been present in very small numbers in the third of the three principal forces involved in the Waterloo campaign: Blücher's Prussian army. In a striking echo of the fictional fate of William Makepeace Thackeray's Barry Lyndon ${ }^{49}$, for example, perhaps as many as three to four hundred captured United Irishmen had been impressed into Prussian service as an alternative to penal transportation after the rebellion of $1798 .{ }^{50}$ This raises the fascinating - though admittedly very tenuous - possibility that some 'legacy' Irish personnel of this sort may have remained in Prussian service long enough to see action during the Hundred Days. More generally, though, no strong tradition of Irish service in German states existed either before, during or after the Napoleonic Wars. ${ }^{51}$

Interesting though both of these avenues undoubtedly are, in the final analysis it appears likely that Irish military service under either French or Prussian arms during the Waterloo campaign could at most have been only marginal. It also remains very difficult to identify evidence that conclusively supports either possibility. By marked contrast, Irish service in the British army during the same episode can be argued to have been vastly more numerically significant. 
In 1815 , that army could boast a number of regiments which possessed formal Irish identities and which generally contained a large overall majority of Irish personnel (Table 1.)..$^{52}$

Table 1. Irish regiments of the British army, 1815. Source: David Murphy, The Irish

Brigades 1685-2006: a gazeteer of Irish military service, past and present (Dublin, 2007).

\author{
Infantry \\ 18th (Royal Irish) Foot \\ 27th (Inniskilling) Foot \\ 83rd Foot \\ 86th (Royal County Down) Foot \\ 87th (Prince of Wales's Own Irish) Foot \\ 88th Foot [Connaught Rangers] \\ 89th Foot \\ 99th (Prince of Wales's Tipperary Regiment) Foot \\ 100th (Prince Regent's County of Dublin Regiment) Foot \\ 101st (Duke of York's Irish) Foot

\section{Cavalry} \\ 4th (Royal Irish) Dragoon Guards \\ 6th (Inniskilling) Dragoons \\ 8th (King's Royal Irish) Light Dragoons \\ 18th (King's Irish) Hussars
}

Some, like the $18^{\text {th }}$ (Royal Irish) Foot or the $6^{\text {th }}$ (Inniskilling) Dragoons, could trace their existences back to the late seventeenth century. Much more recently, war with Revolutionary and later Napoleonic France from 1793 had led to a slew of new Irish regiments being raised as Britain struggled to meet the manpower demands of the ongoing conflict. Regiments like the $87^{\text {th }}$ (Prince of Wales's Own Irish) Foot or the $88^{\text {th }}$ Foot (more popularly known as the Connaught Rangers) dated to this period.

Whether old or new, many of the Irish regiments in British service had experienced noteworthy recent operational service over the course of the Napoleonic Wars. The Peninsular War saw the participation of at least seven Irish regiments, some of whom especially distinguished themselves. ${ }^{53}$ After the battle of Bussaco in 1810, for example, the $1^{\text {st }}$ Battalion of the $88^{\text {th }}$ Foot was singled out for praise by Wellington in his dispatches for executing a timely bayonet charge against attacking French troops. ${ }^{54}$ At the battle of Barrosa the following year the Irish redcoats of the $2^{\text {nd }}$ Battalion of the $87^{\text {th }}$ Foot earned lasting fame for capturing a French Eagle standard - the very first such trophy to be taken in action by British troops during the Napoleonic Wars. ${ }^{55}$

With this background of recent service by Irish regiments in mind, it is interesting to note that the British military contingent which took to the field during the Waterloo campaign contained comparatively few regiments with formal links to Ireland. Only three such units fought under Wellington in 1815: one infantry battalion and two cavalry regiments (Table 2.). ${ }^{56}$ These units were not brigaded together in any sort of unified Irish formation, but rather were dispersed throughout 
Table 2. Irish units of the British army present during the Waterloo campaign. Infantry

1st Battalion, 27th (Inniskilling)

Foot

\section{Cavalry}

6th (Inniskilling) Dragoons

18th (King's Irish) Hussars

There is some contextual explanation for this paucity. As has already been observed, the cessation of hostilities between Britain and France in the spring of 1814 had led to the transferring of a number of experienced British regiments from Europe to North America for service in the War of 1812. Some veteran Irish units had formed part of this exodus across the Atlantic, and so some were either still in America in June 1815 or else travelling back. Other units with Irish identities were engaged in garrison duty in any of dozens of overseas British territories and possessions and so were unavailable at extremely short notice to take part in the Waterloo campaign. ${ }^{57}$

It is perhaps unsurprising that the three formally Irish units which did fight at Waterloo have subsequently become an established focus of attention for historians seeking to summarise Ireland's military role in the campaign. ${ }^{58}$ Certainly, those experiences offer much of interest. All three units saw significant action, which will be assessed in more detail below. But it would be mistaken to conclude that their presence constituted the totality of Irish involvement with the British army at Waterloo.

In fact, a much wider Irish representation can be suggested. Existing secondary study examining the issue at a more general level has repeatedly stressed a very high level of Irish enlistment right across the British army of the Napoleonic period. Edward M. Spiers has opined that:

Irish military participation was particularly prominent in the nineteenth century... some 3,000 to 4,000 [Irishmen] enlisted [into the British army] annually as regular recruits, comprising about one- third of the total intake, and many thousands of militiamen enlisted whenever parliament passed the necessary legislation. Irish recruiting exceeded 90,000 in the fifteen years before Waterloo. ${ }^{59}$

In a similar vein, Richard Holmes noted that by 1830 , only fifteen years after Waterloo, Irish service in the British army had reached a remarkable numerical peak, with some 42.2 per cent of personnel being from the island. ${ }^{60}$ In other words: '... not only were [there] ... regiments which actually bore Irish affiliations composed largely of Irishmen, but several "English" regiments also had many Irish in their ranks" ${ }^{61}$

It is obviously unfeasible in a work of this scale to attempt a definitive statistical survey of all of the ordinary Irish soldiers who may have fought in the British army of the Waterloo campaign. However, contemporary military records can be utilised to provide an introductory impression of the likely extent of enlisted 
Irish service during the episode. As part of the research for this paper, two units drawn from the British portion of Wellington's army of the 1815 campaign - both infantry battalions - were selected more or less at random for detailed statistical study: the $3^{\text {rd }}$ Battalion of the $1^{\text {st }}$ Foot, and the $1^{\text {st }}$ Battalion of the $32^{\text {nd }}$ Foot..$^{62}$ In each, a very substantial proportion of Irish soldiers can be identified as having participated in the campaign (Table 3.).

Table 3. Irish Waterloo campaign veterans $-3^{\text {rd }}$ Battalion, $\mathbf{1}^{\text {st }}$ Foot and $1^{\text {st }}$ Battalion, $32^{\text {nd }}$ Foot.

$\begin{array}{llll} & \text { Total } & \text { Confirmed Irish } & \\ \text { Unit } & \text { strength } & \text { personnel } & \text { Percentage } \\ \text { 3rd Battalion, 1st Foot } & 604 & 224 & 37.08 \% \\ \text { 1st Battalion, 32nd Foot } & 662 & 183 & 27.60 \%\end{array}$

The $3^{\text {rd }}$ Battalion of the $1^{\text {st }}$ Foot contained at least 224 Irish privates and NCOs in June 1815. This represents slightly over 37 per cent of the battalion's overall strength of 604 officers and men at the beginning of the Waterloo campaign. A similarly significant Irish presence is evident in the $1^{\text {st }}$ Battalion of the $32^{\text {nd }}$ Foot. This unit contained at least 183 Irish soldiers of the rank of sergeant and below meaning that a minimum of some 27 per cent of the 662 personnel who began the campaign with the battalion were from the island.

Two points ought to be emphasised in order to properly contextualise this evidence. The first is that both of these figures represent minimum, rather than definitive, totals. Both feature Irish private soldiers and NCOs only, excluding the additional potential presence of Irish officers. As will be suggested below, many British units of the Waterloo campaign contained officers from Ireland as well as ordinary soldiers. Nor, by necessity, are Irish soldiers included who for various reasons are not recorded as having received the Waterloo Medal for their participation in the campaign, such as a number of those killed in action or who died of wounds. Thus, the final number of Irish personnel in each case is likely to have been even higher again.

The second is that neither of these units possessed any sort of formal Irish affiliation in 1815 , or indeed did so at any point during their existences. The $1^{\text {st }}$ Foot was ostensibly a lowland Scottish regiment, while the $32^{\text {nd }}$ Foot was linked to the English county of Cornwall. ${ }^{63}$ Nonetheless, both can be seen to have contained a large number of enlisted Irish personnel. This demonstrates that Irish service in the British army of the Napoleonic period was by no means confined merely to formally Irish regiments.

Although these units were only two out of dozens of individual British battalions and regiments to see service during the Waterloo campaign, there is strong reason to conclude that similar levels of Irish representation are likely to have existed in many, if not an outright majority, of the British units involved in the episode. For one thing, these proportions are entirely in keeping with wider estimations of Irish engagement with the British army during this era, such as those referenced above. They also tally closely with similar detailed assessments of individual British Waterloo units. In his examination of the $2^{\text {nd }}$ Battalion of the $69^{\text {th }}$ Foot during the campaign, for example, Martin Aaron has identified some $35 \mathrm{per}$ cent of that battalion's personnel as being Irish. ${ }^{64}$ As with the two units studied for 
this paper, the $69^{\text {th }}$ Foot did not have any formal connections to Ireland whatsoever in 1815 , being instead an English county regiment affiliated to Lincolnshire. The total figure of Irish military representation in June 1815, then, must have numbered in thousands.

The biographical data obtained for a total of 407 confirmed Irish veterans of the Waterloo campaign across both units also permits some insight into the backgrounds of ordinary Irish soldiers during the episode, and indeed during the wider Napoleonic era. In geographic terms, these soldiers were broadly representative of Ireland as a whole, with personnel coming from all thirty-two Irish counties. The age profile of this group of Irishmen was reasonably mature, with an average age of twenty-six in June 1815. The majority of these men were also experienced soldiers. Some 305 - just short of 75 per cent - had served in the British army for at least two years or more by the time they fought during the Hundred Days. Given that both of these battalions had previously seen service during the Peninsular War, the majority of these Irish soldiers were therefore likely to have fought in at least one or two engagements prior to the Waterloo campaign.

Of particular interest is the fact that a previous civilian occupation can be identified for a majority of these soldiers -393 out of 407 men. These occupations are very starkly weighted in one particular direction (Table 4.).

Table 4. Civilian occupations of Irish Waterloo campaign veterans $-3^{\text {rd }}$ Battalion, $1^{\text {st }}$ Foot and $\mathbf{1}^{\text {st }}$ Battalion, $32^{\text {nd }}$ Foot.

$\begin{array}{lcc}\text { Civilian occupation } & \text { Number } & \text { Percentage } \\ \text { Labourer } & 189 & 49 \% \\ \text { Weaver } & 124 & 31 \% \\ \text { Other } & 80 & 20 \%\end{array}$

The bulk of these Irishmen gave their trade on enlistment either as labourers or else weavers. Only a small minority possessed any sort of alternative skilled trade. This evidence strongly suggests that economic motivation was significant for Irishmen who joined the British army during this period. 'Labourer' is a somewhat ambiguous phrase, which might be used describe recruits ranging from agricultural workers to city dwellers, but it carries a distinct implication of relatively insecure economic circumstances. Certainly, no recruit described thus is likely to have had any formal trade which they could rely on for steady employment. The fact that a large proportion of Irish former weavers are also evident is equally important in this regard. Hand weaving was a traditional trade which was rapidly being squeezed out of existence across the British Isles during the early nineteenth century due to increased industrialisation. Once again, therefore, economic need would appear to have been a key factor in the decisions of Irishmen like these to enlist.

The presence of Irish officers in the British army during the campaign was also quite significant. Naturally, the most prominent of these commissioned Irishmen was the Duke of Wellington himself. Far too much, however, has already been written about his life and career to merit any reappraisal here. It is sufficient to note that the then Arthur Wesley ${ }^{65}$ was born into an aristocratic Irish family with roots in County Meath in 1769 and entered the British army as an ensign (effectively a second lieutenant) at the age of eighteen in 1787 . His native country had featured 
prominently in his early military career, with Wellington serving at Dublin Castle as an aide-de- camp to the then Lord Lieutenant of Ireland, Lord Buckingham, soon after entering the army ${ }^{66}$ By 1815 , he had earned a reputation as Britain's foremost land commander chiefly due to his successes in the Peninsular War and so was a logical choice to command one of the two Allied armies opposed to Napoleon that summer.

Less generally appreciated is the fact that a number of Wellington's key subordinates during the Waterloo campaign were also Irish. ${ }^{67}$ At least three infantry or cavalry brigades within the Anglo-Allied army of 1815 were led by Irish generals. Commanding the $9^{\text {th }}$ British Infantry Brigade was Major General Sir Denis Pack, a native of County Kilkenny whose father, the Very Reverend Thomas Pack, had been Church of Ireland Dean of Ossory during the late eighteenth century. ${ }^{68}$ From a wellestablished Irish aristocratic dynasty, Major General Sir William Ponsonby led the $2^{\text {nd }}$ British Cavalry Brigade - known as the Union or British Brigade from the fact that its three constituent heavy cavalry regiments bore English, Scottish and Irish identities. ${ }^{69}$ His countryman and fellow cavalry brigadier Major General Sir John Ormsby Vandeleur was from an Irish family with connections to both Queen's County and County Clare, and had charge of the $4^{\text {th }}$ British Cavalry Brigade, a light cavalry formation. ${ }^{70}$ All of these Irishmen were highly experienced commanders by 1815 , having previously served in the Peninsula and elsewhere.

At the next level of command down, a number of battalion or regimental commanders in Wellington's army were also from Ireland. Lieutenant Colonel John Millet Hamerton, as an example, came from a County Tipperary family and served as the commanding officer of the $2^{\text {nd }}$ Battalion of the $44^{\text {th }}$ Foot. ${ }^{71}$ When he was wounded during the campaign, command of the battalion passed to another Irishman, Major George O'Malley from County Mayo. ${ }^{72}$ Born in Fahan, County Donegal, Lieutenant Colonel Sir Andrew Barnard commanded the green-jacketed riflemen of the $1^{\text {st }}$ Battalion of the $95^{\text {th }}$ Rifles throughout the campaign ${ }^{73}$; while Major Arthur Rowley Heyland of County Derry was killed in action at the close of the battle of Waterloo leading the $1^{\text {st }}$ Battalion of the $40^{\text {th }}$ Foot. ${ }^{74}$

More junior Irish officers were reasonably liberally represented at the battalion or regimental level. ${ }^{75}$ Irishman Captain Harry Ross-Lewin noted the presence within his battalion of the $32^{\text {nd }}$ Foot of at least four other Irish officers: his younger brother Thomas, who was a lieutenant; as well as a trio of captains. In what Ross-Lewin remembered as a 'rather singular' occurrence, all three Irish captains died as a result of wounds received during the same engagement, at the battle of Quatre Bras on 16 June $1815 .{ }^{76}$ Similar proportions are evident in many other British Waterloounits. The $2^{\text {nd }}$ Battalion of the $69^{\text {th }}$ Foot contained at least three Irish officers $^{77}$, while the $13^{\text {th }}$ Light Dragoons could boast not only an Irish commander, Lieutenant Colonel Patrick Doherty, but also at least four other officers from the country. Two were sons of Lieutenant Colonel Doherty who had followed their father into the army, and both were wounded during the campaign. ${ }^{78}$

Other Irish officers acted in staff or support appointments. Captain Edward Thomas Fitzgerald of County Mayo, for example, served as a deputy assistant quartermaster-general - one of a number of such staff officers charged with responsibility for supply and logistics. ${ }^{79}$ Similarly, Irishmen like Major George de Lacy Evans of County Limerick, an officer of the $5^{\text {th }}$ West Indian Regiment, or 
Captain Edward Keane of the $7^{\text {th }}$ Hussars, from a County Waterford family, served as aides-de-camp to British brigade or divisional commanders. ${ }^{80}$

Finally, though not formal combatants, the presence during the campaign of Irish civilian dependents associated with the British army should not be overlooked. Camp followers of this sort were common in all armies of the Napoleonic era; with women and children accompanying military loved ones on campaign and eking out a subsistence income by providing services like laundry or cooking. ${ }^{81}$

Officially, many of the British units that embarked for Belgium in 1815 were either forbidden entirely from having ordinary soldiers' dependents accompany them in this manner, or else were limited to having only a handful of followers per unit. $^{82}$ In practice, this stricture appears to have been widely flouted; not least by some of the longer serving enlisted personnel in Wellington's army who had only too recently been reunited with their families after lengthy absences on campaign in the Peninsula or North America. To some of these veterans and their loved ones, running the risk of military punishment appeared a more preferable option to enduring the anguish of another separation. ${ }^{83}$

Captain Cavalié Mercer of the Royal Horse Artillery disparagingly noted the presence of Irish camp followers of this sort as he disembarked with his artillery troop at the Belgium port of Ostend in April 1815:

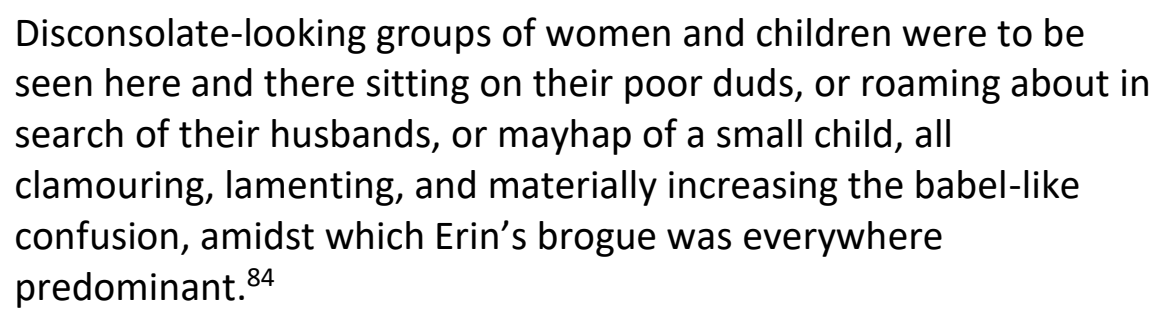

In addition to sharing the same campaign hardships as the soldiers they accompanied, camp followers had to endure the added anguish of uncertainty about the fates of their loved ones once battle was joined. Married to a Welsh private of the $23^{\text {rd }}$ Foot, Irishwoman Jenny Griffiths (sometimes referred to by her later married name, Jones) was typical of the camp followers that travelled with the British army during the Waterloo campaign. Private Lewis Griffiths was wounded at Waterloo, and in the battle's aftermath his wife was forced to search frantically for her spouse before finally locating him. Griffiths recovered sufficiently to allow the pair to settle in Wales after his discharge from the army. ${ }^{85}$

One of the most prominent stories of civilian involvement in the campaign concerns a Mrs McMullen and her husband, a private of the $27^{\text {th }}$ Foot. Given their surname and the fact the $27^{\text {th }}$ was an Irish regiment, the couple are quite likely to have been from Ireland. When Private McMullen fell wounded at the battle of Waterloo, the redoubtable Mrs McMullen is alleged to have helped to carry him from the battlefield, becoming wounded herself in the process. It is usually claimed that she was pregnant during her feat, later giving birth to a baby girl while still in hospital. Both Private and Mrs McMullen are suggested to have survived their experience, with their daughter being christened Frederica McMullen Waterloo; in acknowledgement of both the battle as well as the Duke of York, commander-inchief of the British army, who apparently stood sponsor to the child. ${ }^{86}$ 
It must be concluded that the involvement of Irish military personnel in the Waterloo campaign was very extensive. While there remains at least the possibility that Irish soldiers may have experienced service during the campaign in other European militaries, the overwhelming bulk of Irish service can be demonstrated to have taken place within the British army. Quite apart from the three units present at Waterloo with specific Irish identities, a wider survey of military records suggests that Irishmen are likely to have been present in significant numbers in the ranks of most British battalions or regiments involved in the campaign. The role of Irish officers at Waterloo has also been shown as important, with commissioned Irish soldiers present during the campaign at absolutely every level from subaltern to general. Irish civilians were also involved in events as military dependents.

Indeed, it is possible to go a step further and argue that the British army of the Waterloo campaign offers a genuinely representative cross-section of Irish society at the beginning of the nineteenth century. Irishmen of all descriptions saw active service in 1815. Some, mostly members of the officer class like Major General Sir William Ponsonby or Captain Edward Thomas Fitzgerald, hailed from relatively privileged and influential backgrounds in the country. At the opposite end of the rank and wealth scale at Waterloo were common soldiers like Private Terence Gallagher of Kilmore, County Mayo; a twenty-five year old former weaver who had enlisted into the $1^{\text {st }}$ Foot for a term of unlimited service in December $1813 .{ }^{87}$

\section{PART 4. IRISH MILITARY EXPERIENCES DURING THE WATERLOO CAMPAIGN}

Contrasted against its enduring importance, the Waterloo campaign was a remarkably brief episode. At its shortest definition, the campaign properly hung in the balance for only four full days; from Napoleon's invasion of Belgium early on Thursday 15 June 1815 to the close of the battle of Waterloo itself at nightfall on Sunday 18 June 1815. The intervening period of decision, however, was one of frenetic military activity, and Irish soldiers were involved in numerous aspects of this.

The practical role played by the three specifically Irish units under Wellington's command was significant, particularly at the battle of Waterloo itself. Of special note is the extremely gruelling experience of the Irish soldiers of the $1^{\text {st }}$ Battalion, $27^{\text {th }}$ (Inniskilling) Foot during the battle, which has subsequently become an almost canonical part of Waterloo literature. ${ }^{88}$ The battalion's entry into the campaign had come somewhat late, as it had been based with its parent brigade in the Belgian city of Ghent and had had to conduct a forced march over two days in order to reach the Waterloo position by morning on 18 June. ${ }^{89}$ Ordered forward into the centre of Wellington's line in the middle of that afternoon, the 'Inniskillings' almost immediately formed square: both to ward off French cavalry attacks, and also in order for the battalion to dominate a tactically important road which ran adjacent to its position. This large, cumbersome formation left the unit dreadfully vulnerable to French infantry and artillery fire which duly took a heavy toll as the afternoon and evening of the battle wore on. In the words of an officer of the battalion, Lieutenant Edward Drewe, the Inniskillings were 'exposed... to all that came' ${ }^{90}$.

After approximately six hours, the battalion had suffered some 427 casualties, out of an initial strength of perhaps 750 men - a grave price indeed for so comparatively short a time in action. ${ }^{91}$ To one stunned British eyewitness, it appeared by evening at Waterloo as though: 'the twenty-seventh regiment were 
literally lying dead, in square'. ${ }^{92}$ Though no less appalled at their losses as he watched nearby, Captain Harry Ross-Lewin took some solace in the fact that his countrymen in the Irish battalion had displayed: 'a fine example of steadiness, discipline, and passive courage'.$^{93}$ Due to its frequent featuring in secondary literature, as well as the references to the battalion's stand in a large number of British primary accounts from the battle, it is probably no exaggeration to suggest that the ordeal of the Inniskillings at Waterloo remains perhaps the single most widely discussed and visible element of Irish participation in the campaign. ${ }^{94}$

For all that, the performance of the other two formally Irish units present during the campaign was no less credible, though not perhaps so costly overall. Neither the $6^{\text {th }}$ (Inniskilling) Dragoons nor the $18^{\text {th }}$ (King's Irish) Hussars were significantly engaged at the battle of Quatre Bras on 16 June 1815 , but both took a role in covering the withdrawal of Wellington's army north to the Waterloo position the following day. This was a classic cavalry affair of repeated, scrambling charges and brisk hand-to-hand encounters with the French horsemen harrying the Anglo- Allied force as it marched away through the downpour and mud of an unseasonable summer storm. ${ }^{95}$ County Limerick officer Lieutenant Standish O'Grady of the $7^{\text {th }}$ Hussars described one of these hard-fought rearguard actions in a letter to his father:

We charged the Head of their whole cavalry - their front were Lancers - their flanks were protected for they were in the Street \& the mass of Cavalry in the rear was so great that I defy them to go about. We killed the officer who was in front but we could not reach the men as the lancers of the front and rear kept the men at Bay. [Afterwards] the French pursued us nearly $3 / 4$ of a mile in which they were charged repeatedly by the other Squadron of the $7^{\text {th }}$, but they were too strong for us; we however killed a great many \& got out of the Road at last. ${ }^{96}$

Both Irish cavalry units were fully involved in the battle of Waterloo the following day. Known wryly among military contemporaries as the 'Drogheda Light Horse' or the 'Drogheda Cossacks', after their regimental colonel, the Earl of Drogheda ${ }^{97}$, the $18^{\text {th }}$ Hussars were initially stationed on the extreme left of Wellington's line. On the afternoon of 18 June, they thus became one of the first British units to make contact with Prussian troops of Blücher's army as they started to arrive onto the eastern flank of the battlefield. ${ }^{98}$ Toward the evening of Waterloo, as Napoleon's army began to withdraw from the field, the Irish light cavalry regiment put in in a costly charge intended to maintain pressure on the retreating French. The regiment's commanding officer, Lieutenant Colonel Henry Murray, recounted how this action:

Had been attended with casualty, but retiring [afterwards] proved infinitely more destructive. In returning there was a party of men with me at first; so many fell I do not think another man remained. ${ }^{99}$

More prominent again at Waterloo was the experience of the $6^{\text {th }}$ Dragoons. The Irish regiment was involved in one of the most well-known incidents of the battle: the charge of the British heavy cavalry. When a large-scale French infantry attack threatened the centre of Wellington's line relatively early on during the 
engagement, the British commander's two brigades of heavy cavalry, including the Inniskillings, were ordered forward to intervene.

This cavalry action was initially a marked success, with hundreds of French soldiers becoming casualties or being taken prisoner. Observing the mêlée, Irish staff officer Major George de Lacy Evans described how: 'the enemy fled as a flock of sheep across the valley - quite at the mercy of the dragoons' ${ }^{100}$ But success soon turned to tragedy. Flushed by their achievement, the British heavy cavalrymen recklessly charged on toward the main French position, only to suffer significant casualties in turn at the hands of counter-attacking enemy cavalry.

The commanding officer of the $6^{\text {th }}$ Dragoons, Lieutenant Colonel Joseph Muter, acknowledged afterwards that the Irish horsemen of his regiment, like their peers among the rest of the heavy cavalry: 'went on with so much impetuosity, and suffered severely, both in pursuit and return, from peletons, clouds, or small bodies of French lancers'. ${ }^{101}$ The unit thus ultimately paid a costly price for their charge at Waterloo. Spotting those he described as the 'rollicking Paddies' of the regiment on the march some days later, Captain Cavalié Mercer noted their tattered appearance after the charge:

They had lost more than half their appointments. Some had helmets, some had none; many had the skull-cap, but with the crest cut or broken off; some were on their own large horses, others on little ones they had picked up; belts there were on some; many were without, not only belts, but also canteens and haversacks. ${ }^{102}$

It was during the same charge of the British heavy cavalry at Waterloo that the most high-profile Irish military fatality of the campaign occurred. Major General Sir William Ponsonby's Union Brigade, the parent formation of the Inniskillings, had been at the forefront of the action. While attempting to rally the disordered formation during the latter stages of its charge, Ponsonby was attacked by French lancers and speared to death along with a staff officer of his brigade. Although a number of separate accounts of the Irish general's last moments exist, a recurring theme is that Ponsonby was impeded by riding into a muddy ploughed field, allowing his French pursuers to catch him. ${ }^{103}$ Separated from him, his Irish aide-de-camp Major de Lacy Evans narrowly escaped death himself during the withdrawal of the British heavy cavalry, his horse receiving a sabre cut across its head. He suggested afterwards that his superior's plight had not been helped by the fact that he was mounted on an inferior quality horse:

Poor Sir William Ponsonby might perhaps have been spared to his country had he been better mounted. He rode a small bay hack. He had a handsome chestnut charger, which he meant to mount when real business began, but the groom or orderly who had charge of the chestnut was not forthcoming or within call at the moment the General wanted his horse. ${ }^{104}$

The two other Irish generals present under Wellington during the campaign played relatively important roles along with their commands. Major General Denis Pack's $9^{\text {th }}$ British Infantry Brigade was heavily involved in the battles of Quatre Bras 
and Waterloo as part of Lieutenant General Sir Thomas Picton's $5^{\text {th }}$ (Reserve) Division. This active role in two full scale engagements led to the division suffering by one modern estimation one of the highest casualty rates of any British formation during the campaign. ${ }^{105}$ Pack himself was injured at Waterloo, but remained on the field with his command until the close of the action.

Equally significant was the involvement of Major General Sir John Ormsby Vandeleur. At Waterloo, the Irish general's $4^{\text {th }}$ British Cavalry Brigade was able to cover the withdrawal of the remnants of Wellington's heavy cavalry after their illfated charge. When the overall cavalry commander of the Anglo-Allied army, Lord Uxbridge, was wounded near the close of the battle, Vandeleur took his place for the remainder of the campaign. All three Irish commanders were individually praised in Wellington's victory despatch after the battle of Waterloo, and each received the thanks of Parliament in July $1815 .{ }^{106}$

A number of less senior Irish soldiers nonetheless earned distinction for their actions during the Waterloo campaign. Particularly noteworthy was the case of Corporal James Graham of Clones, County Monaghan; a member of the $2^{\text {nd }}$ Battalion of the $2^{\text {nd }}$ (or Coldstream) Regiment of Foot Guards. ${ }^{107}$ During the battle of Waterloo, the Coldstream company to which the Irishman belonged formed part of the garrison of Hougoumont; a large farm complex situated on the extreme right of Wellington's line. This forward position was a critical one as its fall might enable Napoleon to outflank the main Anglo-Allied line along the ridge of Mont St Jean. Accordingly, Hougoumont was subjected to repeated French assault throughout 18 June 1815.

One of these attacks came perilously close to being decisive when a large group of French soldiers managed to enter the farm through its northern gate. Grasping the danger, a party of soldiers and officers, Corporal Graham amongst them, dashed to the gate and closed it; blocking any further penetration. The entrance secured, the unlucky Frenchmen who had already made it into Hougoumont were unceremoniously hunted down and killed. A number of accounts of the defence credit Graham with two further acts of gallantry over the course of the day: saving the life of a Captain Wyndham by shooting dead an enemy soldier aiming his musket at the British officer, and rescuing his own brother, a fellow soldier, from a burning building which had been set alight by French artillery fire. ${ }^{108}$

Whatever the precise circumstances, the bravery displayed by Graham at Hougoumont ensured him considerable prominence. When an English rector, the Reverend Norcross of Suffolk, wrote to the Duke of Wellington later in 1815 seeking to confer an annual pension on a particularly deserving veteran, Graham was eventually chosen as one of two joint recipients. ${ }^{109}$ Most unusually for an ordinary British soldier of the Napoleonic period, the Irishman's portrait was painted at least once, probably from life, with a version still being held by the National Gallery of Ireland in Dublin. ${ }^{110}$ When Graham died as an in-patient of the Royal Hospital Kilmainham in Dublin in 1845, a number of British journals and newspapers published fulsome obituaries of the soldier described as 'the bravest of the brave at Waterloo - again, a tribute paid to very few common soldiers of the era. ${ }^{111}$

Another Irish soldier noted for his gallantry was Captain Edward Kelly, an officer of the $1^{\text {st }}$ Life Guards. From Portarlington in Queen's County, Kelly distinguished himself on two different occasions during the short campaign. In 
the midst of the Anglo-Allied withdrawal from Quatre Bras on 17 June 1815, he led his cavalry troop in a successful charge against encroaching French lancers. At Waterloo on the following day, Kelly was again to the fore as his regiment attacked during the charge of the British heavy cavalry. There, the Irish officer was responsible for singling out and unhorsing a French colonel. ${ }^{112}$ Dismounting in the middle of the action, Kelly removed the Frenchman's epaulettes as a souvenir of his exploit. 'I got his horse also - a most noble one', he wrote to his wife after the battle, ' - but being attacked by a number of French at the same time, I was obliged to let him go'. ${ }^{113}$ In the same letter, the officer employed a distinctively Irish image to explain the ferocity of the combat at Waterloo: 'Donnybrooke [sic] Fair was nothing to the fight we had here... there were a great number of wigs on the green'. ${ }^{114}$ Kelly's bravery led to him becoming relatively famous within the British army, earning the nickname 'Waterloo' Kelly, and a number of prints and drawings depicting his heroics were published following the campaign.

At least one Irishman became prominent for rather less happy reasons than some of his compatriots, however. Irish peer John Dawson, the $2^{\text {nd }}$ Earl of Portarlington, was an experienced officer who had previously fought in the Peninsula. ${ }^{115}$ In June 1815 , he was serving under Wellington in Belgium as a lieutenant colonel commanding the $23^{\text {rd }}$ Light Dragoons. On the eve of the battle of Waterloo, for reasons which remain unclear ${ }^{116}$, Portarlington absented himself from his regiment as it settled into its bivouac at the Mont St Jean position, and travelled back to the rear toward Brussels. By the time he returned to the field of Waterloo the following day the engagement was already well under way and his regiment had gone into action without him. Desperate to redeem himself, Portarlington attached himself to the $18^{\text {th }}$ Hussars and fought with marked bravery for what was left of the day, having a horse shot from under him near the climax of the battle, but the stain of the incident destroyed his reputation. ${ }^{117}$

Assessed at a more general level, the experiences of most Irish soldiers are likely to have been extremely challenging. The relatively short length of the campaign did not by any means preclude a significant degree of physical and mental hardship. Dependent on their unit, some soldiers in Wellington's army had to fight in two full- scale, costly battles at Quatre Bras and Waterloo; with an interval of only a single day in between. Were this not enough, most had to do so while increasingly hungry, fatigued and all the while subject to the vagaries of weather. Corporal Edward Costello remembered that the more inexperienced recruits of his battalion quickly came to rue the fact that they had not thought to take their full share of rations with them when they marched out from Brussels at the beginning of the campaign. ${ }^{118}$ For Captain Harry Ross-Lewin and his men, the early morning of Waterloo was spent trying to dry out their soaked and muddy uniforms after a miserable and presumably largely sleepless night spent out in the open under rain. ${ }^{119}$

The practical experience of battle and its aftermath was invariably horrific, and it stands as a necessary counterpoint to the potential colour and romanticism of the Napoleonic era to reflect on this. The short range and comparative unreliability of early nineteenth century weaponry like muzzle-loading, black powder small arms and artillery meant that engagements were frequently fought at relatively intimate distances. At Waterloo, for example, the Anglo-Allied and French armies began the day separated in some places by only around 300 metres. ${ }^{120}$ The battlefield overall was remarkably compact. One historian has noted that the area was scarcely larger than New York's Central Park; astonishing when it is considered that some 200,000 
soldiers of all nationalities manoeuvred back and forth on the site over the course of 18 June $1815 .^{121}$

Soldiers at the forward edge of battle were subjected to a disorientating and frightening cacophony of gunfire, shouts and screams. Confusion was increased by the fact that the massed firing of black powder weapons quickly produced thick, acrid clouds of smoke which choked combatants and greatly obscured their vision. County Armagh native Major Dawson Kelly described how at Waterloo: 'the fog and smoke lay so heavy and thick on the ground that we could only ascertain the approach of the enemy by the noise and clashing of arms which the French usually make in their advance to attack'. ${ }^{122} \mathrm{~A}$ prolonged engagement on the scale of Quatre Bras or Waterloo might require infantrymen in particular to remain in close order ranks for hours; under fire, and with no opportunity to relieve themselves save for where they stood.

Contemporary weaponry, though decidedly unsophisticated and inefficient by modern standards, was nonetheless capable of inflicting appalling damage. An anonymous officer of the $32^{\text {nd }}$ Foot recounted the death at Quatre Bras of Irishman Captain Edward Whitty. He was killed when a bursting French shell 'took away the silk of the regimental colour and the whole of the right section of the fifth company, amongst whom was my lamented friend, Captain Whitty; his head was literally blown to atoms'.123

The scale of the campaign's casualties, perhaps made all the more shocking by the relatively short space of time that they had occurred in, affected even seasoned Irish soldiers. Writing four days after the battle of Waterloo, Lieutenant Hugh Boyd Wray from Queen's County dolefully recorded in his diary the losses suffered amongst his brother officers of the $40^{\text {th }}$ Foot:

... Poor Fisher was hit, I was speaking to him, and I got all over his brains, his head was blown to atoms. Poor Major Heyland (who commanded) was shot through the heart, and Poor Ford was shot thro' the spine of his back, but did not die for a short time after he was carried away. Poor Clarke lost his left arm and I am much afraid Browne will lose his leg, he is shot thro' the upper part of the thigh and the bone terribly shattered. There are eight more of our officers wounded, but all are doing well except little Thornhill, who was wounded thro' the head. ${ }^{124}$

It is little exaggeration to suggest that soldiers who were destined to receive serious injuries were almost better off dying more or less instantly, as the plight of those wounded during the campaign was truly dreadful. On the morning after Waterloo, Captain Cavalié Mercer came across: 'two Irish light-infantry men sending forth such howlings and wailings, and oaths and excretions, as were shocking to hear. One of them had his leg shot off, the other his thigh smashed by a cannonshot. They were certainly pitiable objects' ${ }^{125}$ So many combatants of all nationalities were wounded, especially at Waterloo, that military medical services were simply overwhelmed. ${ }^{126}$ One awful consequence of this was that many critically injured soldiers were forced to remain where they had fallen for anything up to days before being recovered and treated. Unsurprisingly, many did not survive the delay. Those who did would not quickly forget the experience. 
Lieutenant Colonel Frederick Ponsonby, the commanding officer of the $12^{\text {th }}$ Light Dragoons, was from the same wider Irish aristocratic family as his more wellknown cousin Major General Sir William Ponsonby. Seriously wounded leading his regiment at Waterloo, Ponsonby was unhorsed and left helpless on the battlefield until the following morning. In the agonizing interval, he was vindictively wounded once again by a French lancer, who spotted him struggling to raise himself and ran his lance through his back, exclaiming: 'Tu n'est pas mort, coquin [you're not dead, you rascal]' ${ }^{127}$ Incapable of defending himself, Ponsonby also had to contend with the predatory attentions of passing plunderers of all nationalities; keen on robbing him of what few valuables he had about his person.

A similar ordeal was experienced by Troop Sergeant Major Matthew Marshall from County Down, a member of the $6^{\text {th }}$ Dragoons. Knocked from his mount and badly wounded at Waterloo, Marshall had to wait where he lay for two days and three nights before being found and removed from the field. Remarkably, the Irish NCO survived to receive his discharge and pension from the army and settle in Belfast, where he died in $1825 .^{128}$

Even when a wounded soldier did receive relatively prompt medical treatment, his situation was still generally an unenviable one. Contemporary methods of treatment for combat injuries were often extremely crude and painful. Amputation of limbs, for example, almost always carried out without any anaesthetic save perhaps a few rushed gulps of gin or brandy, was a common recourse for injuries to extremities like arms and legs. When Lieutenant Colonel Frederick Ponsonby eventually reached the surgeons after his injuries at Waterloo, he was subjected, in accordance with the prevailing medical wisdom of the period, to a strict regimen of bleeding: ' 120 ounces in two days'. ${ }^{129}$ That he recovered and lived until 1837 was undoubtedly more in spite of, rather than because of, treatment of this sort.

Some Irishmen wounded during the campaign lingered on in pain and discomfort for weeks afterwards before eventually expiring. Dubliner Private James Cain of the $1^{\text {st }}$ Battalion of the $32^{\text {nd }}$ Foot, for example, died in hospital at Antwerp on 9 July $1815 .{ }^{130}$ From the same battalion, County Fermanagh man Corporal William Ramsay clung to life until 28 July $1815 .{ }^{131}$

The Irish soldiers involved in the Waterloo campaign underwent, then, a range of significant experiences. The specifically Irish units present during the episode all played reasonably central roles, as did senior commanders from the country. Other Irishmen earned distinction for acts of particular bravery. At a wider level, the reality of the campaign and of battle for the majority of Irish combatants in 1815 was likely to have been extremely mentally and physically demanding.

\section{PART 5. IRELAND AND THE AFTERMATH OF HOSTILITIES}

The aftermath of the Waterloo campaign had a considerable impact on Ireland. A very significant level of Irish interest in the episode was demonstrated through a variety of forms of commemoration and acknowledgement. The campaign also had an important human legacy, with the many Irish veterans of the affair going on after 1815 to have a range of post-conflict experiences.

Popular Irish reaction to the initial news of the Allied victory in Belgium was generally enthusiastic. On 26 June 1815, the Freeman's Journal was one of the first 
Irish newspapers to publish the Duke of Wellington's now famous Waterloo despatch; which provided the first full account of the military events which had taken place in Belgium. ${ }^{132}$ In its covering remarks, the battle of Waterloo was noted by the newspaper as having been 'a terrible action - perhaps the most terrible that it ever fell to the lot of the historian to record'. ${ }^{133}$

Public celebrations ensued in many of the island's main cities. In Dublin, illuminations were staged to mark the victory. ${ }^{134}$ The memory of the astonishing news of the campaign arriving in the summer of 1815 would be recalled as a defining moment by some Irish people well into their dotage. When a Mrs Healy of Croghan, County Roscommon, for example, died at the age of one hundred and ten in October 1910 , it was observed that to the end of her long life, one of her most enduring recollections was of hearing of the Allied victory as a teenage girl. ${ }^{135}$

After Napoleon's second and final abdication at the end of June 1815, many units within the British portion of Wellington's force remained in France, in some cases until as late as 1818 , as part of an Allied army of occupation. ${ }^{136}$ In the short term, this precluded any sort of large scale, victorious military homecoming in Ireland. Nonetheless, individual Irish soldiers who travelled back from the Continent or who corresponded with family and friends found a domestic audience with an evidently keen appetite for first-hand accounts of the campaign. Obtaining leave in December 1815, Captain Harry Ross-Lewin described returning home 'to tell long stories to my friends' ${ }^{137}$

The episode was discussed and dissected at great length in Ireland. Writing from camp on the outskirts of Paris to his father in County Limerick, Lieutenant Standish O'Grady felt obliged to correct malicious gossip about his regiment, the $7^{\text {th }}$ Hussars, which he learnt had been circulating in the country: 'judge then our feelings when informed that a Report to our disadvantage had spread itself in London \& I perceive by your question about the flags on the lances frightening our horses that it had also reached Dublin'. ${ }^{138}$

Within weeks of the Waterloo campaign, more constructive Irish engagement had begun to occur. By August 1815, contributors across the country were recorded as responding generously to a subscription fund opened:

... For the special Relief and Benefit of the families of the brave Men killed, and the wounded Sufferers of the BRITISH ARMY, under the command of our ILLUSTRIOUS COUNTRYMAN THE DUKE OF WELLINGTON, in the SIGNAL VICTORY OF WATERLOO [sic]. ${ }^{139}$

From the very aftermath of the campaign, the battlefields over which it had been fought became sites of near pilgrimage for travelers from across the British Isles. The significance of the Allied victory, combined with the practical fact that the scene of that achievement was so accessible, just across the English Channel, led to large scale British tourism taking place. One historian of the campaign has noted that the battlefield of Waterloo in particular effectively became the first theme park in Europe ${ }^{140}$ during the nineteenth century. Irish tourists were amongst the curious sightseers drawn to Belgium in subsequent years to trace the footsteps of the armies of 1815. By June 1865, a correspondent of the Irish Times, reporting from Waterloo for the battle's fiftieth anniversary, could report the favourable impression that visitors from the country had apparently made on locals: 
"There are some [declared a Belgian omnibus operator] who laugh loudly, and talk to everyone, and especially to ladies, but I learned a secret at last about these gentlemen." "What was that? - that they were really pickpockets?" "Oh Lord, no, monsieur, they are not pickpockets, but though we call them Anglais, they are really not English; they are - they are - Irishmen!". ${ }^{141}$

Irish people who could not travel to the Continent could still indulge their fascination by patronising a range of displays and exhibitions which sought to capitalize on public interest in the Waterloo campaign. In December 1818, for example, an advertisement for a Waterloo panorama on show near Dublin's Eden Quay noted that the attraction depicted: 'nine different interesting periods of the battle, with figures as large as life, printed on nearly 10,000 square feet of canvas'. ${ }^{142}$ Overwhelming public demand in Dublin had led to the panorama's run being extended.

A prolific flurry of patriotic naming, just as across the rest of the British Isles, eventually saw dozens of Irish streets, structures and even settlements titled after the most famous battle of the 1815 campaign. By the middle of the nineteenth century, Dublin alone could boast a Waterloo Road, Avenue, Terrace and Place; as well as a number of private dwellings named for the eponymous southern Belgian town. ${ }^{143}$ Near Mallow in County Cork, there remains to the present an entire village called Waterloo - one of a number of Irish settlements which have historically borne the title.

Some individual soldiers who had fought during the campaign were also commemorated in this fashion. As both an Irishman and as one of the two Allied commanders responsible for victory in 1815, the Duke of Wellington figured especially prominently in this regard. ${ }^{144}$ The most grandiose physical tribute to the Irish soldier in his native country was, and remains, the Wellington Testimonial in Dublin's Phoenix Park; a 62 metre tall obelisk with bronze panels at its base depicting highlights of his career, including the battle of Waterloo. ${ }^{145}$ Described in an 1821 guide to Dublin as an expression 'of gratitude to the illustrious deliverer of our country'146, work commenced on the testimonial in 1817 but was not finally completed until 1861 due to a shortage of funds. For a long period during the nineteenth century, the area of the Phoenix Park around the testimonial appears to have been the scene of an annual military review on or around Waterloo Day, 18 June. ${ }^{147}$

The Waterloo campaign had a discernible cultural impact within Ireland, with a significant number of plays, songs and verses drawing inspiration from and featuring the episode. Irish poet Edmund Lenthal Swifte paid tribute to the victory in a poem published in November 1815: 'That day! - what grief, what glory, marked that day! / Tears dim our triumphs, triumphs dry our tears'. ${ }^{148}$ Another example of Waterloo-inspired verse, published anonymously in Dublin in 1817, drew specific attention to the contribution of Irish soldiers to the campaign: '... Erin's faithful soil, whose martial race / Their emerald isle with proudest laurels grace'. ${ }^{149}$

Several songs and ballads which circulated in Ireland in the years following 
1815 took the Waterloo campaign as their theme. A collection of song books printed in County Monaghan in 1822 includes a mournful contemporary ballad about a bereaved woman whose lover was 'Low buried in oblivion beside many a hero too / There to decay and mould away on the plains of Waterloo'. ${ }^{150}$ The campaign was also depicted on stage for Irish audiences. Around 1825, for example, Dublin theatregoers could enjoy a dramatic recreation of Waterloo at the city's Theatre Royal on Hawkins Street. ${ }^{151}$

The post-conflict experiences of the Irish men and women who had been directly involved in the Waterloo campaign were distinctly varied. In an immediate sense, Irish soldiers who had served with the British army during the Waterloo campaign benefited from a number of tangible rewards. All were eligible for prize money, awarded proportionately according to rank. By one estimation, privates were entitled to around $£ 2$, with lieutenants receiving around $£ 35 .{ }^{152}$ These were by no means inconsiderable sums when it is considered that the daily pay for a British infantry private averaged a nominal 1 shilling during the Napoleonic Wars. ${ }^{153}$ Waterloo veterans were also accorded the benefit of two years' extra service, gratis; of assistance for retirement and pension purposes.

By far the most prominent honour bestowed upon veterans was the Waterloo Medal. In acknowledgement of the episode's particular significance, the aftermath of Waterloo marked the very first time that the British army awarded a general campaign medal. The award was commendably egalitarian, with an identical medal issued to all eligible personnel regardless of rank or role in the fighting. The decoration itself was silver, with Britain's then Prince Regent (later King George IV) depicted in profile on one face and a symbolic representation of the goddess Victory on the other. The details of the recipient's name, rank and regiment were impressed around the rim of the medal, which was suspended from a crimson ribbon with blue edging. ${ }^{154}$ Some 39,000 Waterloo Medals were eventually issued.

Corporal Edward Costello recorded his pleasure at receiving what he termed this 'honourable badge' along with the rest of his battalion at the beginning of 1816. ${ }^{155}$ For a number of Irish Waterloo veterans like him, the medal remained a cherished possession to the end of their days. ${ }^{156}$ Richard Chambers was a native of County Dublin who had fought during the campaign as a drummer with the $69^{\text {th }}$ Foot. ${ }^{157}$ At his death in 1845, having settled in England following his discharge from the army, his obituary in a local newspaper noted that the Irishman's Waterloo Medal '... was considered by the deceased to be his greatest ornament' ${ }^{158}$ On his death bed, Chambers had directed that the medal never leave his family. ${ }^{159}$ When County Fermanagh man Charles Hall died as an in-pensioner of the Royal Hospital Kilmainham in December 1878 , the former private of the $32^{\text {nd }}$ Foot left his prized Waterloo Medal, still in immaculate condition, as a bequest to the institution which had cared for him in his old age. ${ }^{160}$

In the longer term, however, the prospects for many Irish soldiers who had served during the campaign were not necessarily positive. This was especially true of ordinary soldiers. Those who lived to complete their full term of service and be discharged from the army left with very little in the way of transferable skills or education, and were frequently infirm due to wounds as well as the practical toll of years of a very physically demanding lifestyle. The discharge records of many Irish Waterloo veterans highlight this. From County Wexford, for example, Private 
Patrick Molloy of the $52^{\text {nd }}$ Light Infantry was discharged in May 1823 at the age of forty one; being described simply as 'unfit for military duties in consequence of age and length of service'. ${ }^{161}$ Molloy had also been severely wounded in the right arm during the Waterloo campaign. ${ }^{162} \mathrm{~A}$ similar case was that of Private Robert O'Hara, from County Down. An infantryman of the $1^{\text {st }}$ Foot, O'Hara was discharged from the army at the age of thirty seven in August 1826, still bearing the scars of two significant gun shot injuries: one suffered during the siege of San Sebastián in Spain in 1813 , and one dating from the Waterloo campaign. ${ }^{163}$

In the decades following the campaign, many veterans and their dependents struggled with financial and personal hardship. Although many soldiers were eligible for a military pension upon discharge, dependent on the length and nature of their service, this did not always prove sufficient for their long term needs. Having petitioned unsuccessfully for an increase on the pension he was awarded following his discharge from the $95^{\text {th }}$ Rifles in 1819 , Edward Costello claimed to have been driven in desperation to the very verge of criminality. Lying in wait to mug a passerby, the Irishman was saved from embarking on a life of crime due only to the fact that the first prospective victim he came across was an old army comrade who took him in and assisted him. ${ }^{164}$

Royal Artillery veteran Henry Magee from County Down had served through the Peninsular War and during the Waterloo campaign, where he was wounded in the right leg by a musket ball. Having angrily rejected the paltry pension that was offered to him upon his discharge from the army in 1815, Magee eventually fell into very strained financial circumstances. In his old age in 1868, the Waterloo veteran had to be assisted by a subscription raised amongst wealthy gentlemen of his area. ${ }^{165}$

In September 1884, an officer based at the Curragh Camp in County Kildare was driven to write to the Irish Times in order to draw attention to the pathetic plight of local 'Waterloo woman' Ann Griffin. Griffin's husband had fought with the $51^{\text {st }}$ Light Infantry in the Peninsula and at Waterloo, where he was twice wounded; and four of her sons had gone on to serve their country in the same regiment. Aged eighty six, Griffin had never benefited from any kind of state support, and, increasingly infirm, was totally dependent on charity. ${ }^{166}$

Individual stories such as these permit the observation that many ordinary Irish soldiers did not receive the full support and thanks of a grateful nation; which they had arguably earned after having contributed to the great victory of 1815 . However, this was not universally the case. A number of Irish Waterloo veterans were fortunate enough to gain admission in later life as in-pensioners of the Royal Hospital in Chelsea, London, and its sister institute in Dublin, the Royal Hospital Kilmainham. In the latter, old soldiers like County Wexford brothers Robert and Thomas Freeman, who had both served during the campaign with the $52^{\text {nd }}$ Light Infantry, were able to see out their days in security and comfort amongst fellow veterans. ${ }^{167}$ An early twentieth century history of the Royal Hospital Kilmainham described how its in- pensioners enjoyed passing: 'their well-earned ease with draughts, newspapers, exchanges of reminiscences, or the settlement of the nation's foreign and domestic policy'. ${ }^{168}$

Some Irish soldiers present during the Waterloo campaign went on to enjoy significant later professional success. George de Lacy Evans, for example, who had 
served in June 1815 as an aide-de-camp to his countryman Major General Sir William Ponsonby, became prominent later on in the nineteenth century as a general in his own right. In 1835-37, he commanded the volunteer British (or Auxiliary) Legion which fought in Spain during the First Carlist War. ${ }^{169}$ During the Crimean War of 1853-56, he led the $2^{\text {nd }}$ British Division, and was one of relatively few British senior commanders to emerge from that conflict with a largely favourable reputation. ${ }^{170}$

Another native of Ireland, Charles Rowan from County Antrim, had seen distinguished military service with the British army and had been wounded at Waterloo as a major of the $52^{\text {nd }}$ Light Infantry. ${ }^{171}$ In 1829 , along with a fellow Irishman, barrister Richard Mayne from Dublin, he became one of the two first joint commissioners of London's Metropolitan Police. Rowan's influence on the embryonic police force, especially his military emphasis on good discipline and deportment, has been noted as important to its early success. ${ }^{172}$

Several Irish veterans of the campaign lived to quite substantial old age, and their experiences are perhaps as appropriate a place as any other to end an assessment of Ireland's lasting links to the episode. From Tandragee, County Armagh, Samuel Gibson served with the $27^{\text {th }}$ Foot from 1803 to 1815, and was present at the battle of Waterloo. He died in a workhouse in Caterham, Surrey, in December 1891, having apparently reached the age of one hundred and one. ${ }^{173}$ The old Irish soldier was buried with full military honours and speculation ensued about whether or not he might be considered Britain's last ever veteran of the Waterloo campaign.

However, that distinction was ultimately to go to another Irishman, Maurice Shea of County Kerry. Born near Tralee in 1795, Shea enlisted into the British army at the age of eighteen in 1813. ${ }^{174}$ In June 1815, he fought in Belgium as a private in the $2^{\text {nd }}$ Battalion of the $73^{\text {rd }}$ Highlanders. Leaving the army as a corporal in 1822, Shea subsequently served with the British Legion in Spain and eventually settled in the town of Sherbrooke, in the Canadian province of Quebec. ${ }^{175}$ When he died there in March 1892 at the age of ninety-seven, he was generally credited as having been the very longest-lived British veteran of the 1815 campaign - an honour he retains to the present. ${ }^{176}$

It is clear that the Waterloo campaign had an impact on Ireland which went well beyond the immediate events of 1815 . The episode was widely celebrated and discussed within the country, and was acknowledged in a number of different fashions, from cultural representation to tourism. Waterloo also resulted in an important Irish human legacy. The many Irish veterans of the campaign went on subsequently to a range of different experiences. In the long term, some suffered with personal hardship, while others went on to lead successful, and in some cases remarkably lengthy lives into the nineteenth century.

\section{CONCLUSION}

As its bicentenary draws near at the beginning of the twenty-first century, the Waterloo campaign remains a significant event in modern history. Although vastly more destructive conflicts than the Revolutionary and Napoleonic Wars have since occurred, and although the balance of European and global power has shifted several times since 1815 , Waterloo continues to have importance and relevance. It 
produced a decisive conclusion to more than a quarter of a century of European instability, and ruled out for the remainder of the nineteenth century the possibility of any single Continental power enjoying unchecked hegemony. The campaign itself involved the practical participation of hundreds of thousands of individuals, from a score of modern European countries, and was witnessed, discussed and remembered by countless more.

Ireland's connections to this episode are substantial. Irish soldiers were present in large numbers within the Anglo-Allied army commanded by the Duke of Wellington. While settling on a definitive figure for Irish military representation during the campaign has been understandably unfeasible for an examination on this scale, it seems likely that that figure must number in thousands rather than hundreds. These Irish personnel were not merely mute extras as military events progressed. Irishmen served in a huge range of different capacities, with some natives of the island occupying senior and influential command positions. Other Irish soldiers distinguished themselves by their gallantry in action, and earned contemporary attention and acclaim. The specifically Irish military units present, although little in number in comparison to previous British campaigns of the Napoleonic era, nonetheless fought extremely credibly and were involved in a number of the campaign's more significant moments. Irish civilians were also present as the opposing armies clashed in Belgium in June 1815, in the role of military dependents following their loved ones to war.

The campaign also had an important and recognizable domestic impact in Ireland, both before and after its conclusion. The initial excitement and drama of Napoleon's return to power in France was reflected both in contemporary Irish reportage and in private correspondence. Preparations for war had a notable practical effect on the island, with a number of British units destined to see service in the Waterloo campaign being stationed across Ireland. The aftermath of Waterloo saw a significant level of domestic Irish engagement with the episode. Events in 1815 were acknowledged through widespread popular celebration and memorialization, which demonstrated a high level of contemporary Irish interest in what had taken place. The subsequent experiences of Irish people who had been directly involved in the campaign were also important, with some experiencing personal difficulties and hardship and others going on to achieve professional success and fortune.

Due to inherent practical limitations on space and scale of research, this thesis cannot pretend to be an utterly definitive examination of Ireland and the Waterloo campaign. However, more than enough connections of significant relevance have been identified to support a conclusion that the episode ought certainly to be considered as important to both Irish military and social history. With this in mind, it might seem curious that the campaign remains generally underappreciated and under- acknowledged in contemporary Ireland. It is referred to and discussed comparatively infrequently today, and as yet there appear to be no plans for any official Irish commemorations of the campaign's bicentenary in 2015. However, some explanation for this can be suggested.

For one thing, it is not perhaps surprising that general Irish appreciation of the country's role in events is less than keen when existing secondary study of the campaign consistently makes little detailed reference to that role. Although a minority of aspects of Irish involvement have been the subject of repeated 
examination over the decades, like the career of the Duke of Wellington or the experiences of some of the Irish units in the 1815 campaign, other features have not received anything close to the same attention. Astonishingly few of the many secondary works on the Waterloo campaign consulted for this thesis, for example, specifically note the Irish backgrounds of senior military figures like Major Generals Pack, Ponsonby or Vandeleur, or of other prominent soldiers like or Corporal James Graham or Captain Edward Kelly. Similarly, many otherwise detailed regimental histories fail to mention the presence of various British units in Ireland in 1814-15, as well as the military activity that took place in the country upon Napoleon's resumption of power in 1815.

The fact that the majority of Ireland's connections to the Waterloo campaign are inextricably linked with Britain and the British military may also have contributed to a lack of modern Irish interest in the episode, in particular within the Republic of Ireland. As David Murphy has pointed out in relation to the issue of Ireland and the Crimean War, if it is only within the last two decades or so that the much more extensive and costly pattern of Irish service in the British armed forces during the First World War has belatedly received its full share of domestic attention, then it stands to reason that earlier instalments of Irish interaction with the British military have potentially been overlooked. ${ }^{177}$

The campaign may also suffer from a lack of immediacy, due to the obvious passage of time that has occurred since 1815. While there are perhaps many Irish people today might be at least dimly aware of a grandfather or great-grandfather who served at Gallipoli or on the Somme, knowledge of an ancestor who fought under Wellington may very well be more limited, which may in turn have had an effect on popular Irish interest in Waterloo and the wider era of the Napoleonic Wars.

It can still be hoped, however, that the approaching major anniversary of the Waterloo campaign may help to stimulate refreshed interest in Irish links to this important historical episode, both within Ireland and further afield. If the research presented above makes even the most modest of contributions toward this, then something worthwhile will arguably have been achieved. 


\section{Appendices}

(i) Irish Waterloo campaign veterans $-3^{\text {rd }}$ Battalion, $1^{\text {st }}$ Foot

\begin{tabular}{|c|c|c|c|c|c|}
\hline Name & Rank & Age & County & Enlisted & Trade \\
\hline Adams, Thomas & Private & 31 & Antrim & July 1808 & Not available \\
\hline Allen, John & Private & 30 & Monaghan & March 1807 & Weaver \\
\hline Austin, William & Private & 36 & Armagh & December 1807 & Weaver \\
\hline Bell, Isiah & Private & 23 & Armagh & November 1810 & Weaver \\
\hline Benson, James & Private & 34 & Donegal & July 1807 & Weaver \\
\hline Bloxham, Richard & Sergeant & 48 & Dublin & May 1802 & Painter \\
\hline Bloxham, William & Corporal & Not available & Dublin & November 1813 & Servant \\
\hline Boland, James & Private & 32 & Clare & January [?] 1808 & Tailor \\
\hline $\begin{array}{l}\text { Boucher, William } \\
\text { Brannagan / }\end{array}$ & Private & 28 & Dublin & February 1814 & Shoemaker \\
\hline Brannaghan, Matthew & Corporal & 17 & Antrim & June 1813 & Weaver \\
\hline Brown, William & Private & 29 & Antrim & August 1810 & Weaver \\
\hline Buckley, Denis & Private & 18 & Cork & May 1815 & Labourer \\
\hline Burns / Burnes, Edward & Private & 30 & Down & November 1808 & $\begin{array}{l}\text { Weaver } \\
\text { Cotton }\end{array}$ \\
\hline Burns, Bernard & Private & 28 & Antrim & May 1812 & Spinner \\
\hline Burns, James & Private & 26 & Louth & August 1811 & Labourer \\
\hline Burns, Matthew & Private & 24 & Dublin & May 1812 & Rope Maker \\
\hline Canning, Hugh & Sergeant & 27 & Derry & March 1808 & Not available \\
\hline Carrigan, Hugh & Private & 28 & Fermanagh & June 1811 & Labourer \\
\hline Carroll, Edward & Private & 26 & Westmeath & November 1811 & Labourer \\
\hline Carroll, Patrick & Private & 21 & Mayo & May 1813 & Labourer \\
\hline Carson, Hill & Private & 23 & Down & May 1812 & Weaver \\
\hline Christie, Robert & Private & 39 & Derry & September 1806 & Weaver \\
\hline Clarke, Charles & Private & 33 & Louth & April 1812 & Carpenter \\
\hline Clarke, Frederick & Corporal & 29 & Westmeath & June 1807 & Labourer \\
\hline Clarke, John & Private & 27 & Down & November 1809 & Labourer \\
\hline Coates / Coats, John & Private & 29 & Antrim & January 1809 & Weaver \\
\hline Coleman, Patrick & Private & 27 & Carlow & February 1811 & Carpenter \\
\hline $\begin{array}{l}\text { Colopy / Collopy, } \\
\text { Edward }\end{array}$ & Private & 50 & Limerick & February 1801 & Labourer \\
\hline Coogan, Owen & Private & 28 & Monaghan & October 1807 & Weaver \\
\hline Cooley, John & Private & Not available & Dublin & May 1812 & Labourer \\
\hline Corbett, John & Private & 46 & Clare & November 1807 & $\begin{array}{l}\text { Not available } \\
\text { Stocking }\end{array}$ \\
\hline Cosgrove, Peter & Drummer & 17 & Fermanagh & June 1813 & Weaver \\
\hline Craig, John & Private & 26 & Down & February 1807 & Labourer \\
\hline Crawford, Robert & Private & 34 & Fermanagh & February 1808 & Shoesmith \\
\hline Croagan / Crogan, John & Private & Not available & Dublin & January 1811 & Labourer \\
\hline Culbert, Elias & Private & 24 & Antrim & May 1812 & Weaver \\
\hline Cunningham, James & Private & 28 & Donegal & July 1809 & Weaver \\
\hline Curray, James & Private & Not available & Limerick & September 1808 & Slater \\
\hline Curren, Henry & Private & 18 & Tyrone & January 1812 & Labourer \\
\hline Cuthbert, Thomas & Private & 34 & Antrim & November 1808 & Labourer \\
\hline Daley, Jeremiah & Private & 29 & Dublin & April 1806 & Coffin Maker \\
\hline Delahunty, Thomas & Corporal & 24 & Carlow & October 1814 & Not available \\
\hline Delaney, Michael & Private & 31 & Tyrone & October 1807 & Labourer \\
\hline Develin, William & Private & Not available & Tyrone & November 1814 & Labourer \\
\hline Dewart, William & Private & 29 & Down & May 1808 & Weaver \\
\hline
\end{tabular}




\begin{tabular}{|c|c|c|c|c|c|}
\hline Dickey, William & Private & 28 & Antrim & June 1807 & Weaver \\
\hline Dillon, James & Private & 32 & Kildare & February 1807 & Labourer \\
\hline Donaghoe, Michael & Drummer & 29 & Tyrone & August 1806 & Labourer \\
\hline Donnally, John & Private & 31 & Armagh & April 1808 & Shoemaker \\
\hline Dougherty, Hugh & Private & 22 & Donegal & August 1811 & Labourer \\
\hline Dougherty, Nicholas & Private & Not available & Donegal & February 1814 & Shoemaker \\
\hline Downie, Bartholomew & Private & 20 & Kerry & November 1814 & Labourer \\
\hline Downie, John & Corporal & 22 & Roscommon & August 1813 & Labourer \\
\hline Downs, Hugh & Sergeant & 35 & Donegal & August 1811 & Weaver \\
\hline Enright, Matthew & $\begin{array}{l}\text { Sergeant } \\
\text { Either } \\
\text { Drummer or }\end{array}$ & 27 & Limerick & November 1807 & Shoemaker \\
\hline Evans, Thomas & Private & 37 & Limerick & April 1808 & Labourer \\
\hline Fair, Michael & Corporal & 26 & Mayo & December 1811 & Weaver [?] \\
\hline Farrell, John & Private & 47 & Dublin & July 1806 & Tailor \\
\hline Farrell, Robert & Private & 28 & Longford & November 1807 & Shoemaker \\
\hline Finley, James & Private & 22 & Monaghan & June 1812 & Weaver \\
\hline Fisher, James & Private & 19 & Antrim & March 1813 & Labourer \\
\hline Flanagan, John & Sergeant & 34 & Clare & May 1811 & Labourer \\
\hline Flynn, Denis & Private & 26 & Mayo & September 1812 & Labourer \\
\hline Flynn, Patrick & Private & 30 & Tipperary & September 1812 & Labourer \\
\hline Fullerty, William & Private & 25 & Derry & February 1810 & Weaver \\
\hline Fulton, John & Private & 20 & Derry & September 1814 & Labourer \\
\hline Gaffney / Gaffrey, John & Private & 24 & Dublin & May 1812 & Carpenter \\
\hline Gallagher, Martin & Private & 27 & Mayo & July 1812 & Labourer \\
\hline Gallagher, Terence & Private & 25 & Mayo & Dec 1813 & Weaver \\
\hline Gallinagh, Daniel & Private & 31 & Derry & May 1808 & Labourer \\
\hline $\begin{array}{l}\text { Galloway / Gallaway, } \\
\text { William }\end{array}$ & Private & 27 & Antrim & 1808 & Carpenter \\
\hline Garvey, Peter & Private & 26 & Longford & May 1812 & Weaver \\
\hline Gaughegan, Patrick & Corporal & 33 & Longford & April 1807 & Labourer \\
\hline Gaven, Michael & Private & 23 & Mayo & November 1811 & Labourer \\
\hline Gibson, James & Private & 25 & Monaghan & November 1807 & Weaver \\
\hline Gilleland, Robert & Private & 27 & Antrim & May 1808 & Baker \\
\hline Gillespie, David & Corporal & 25 & Down & September 1814 & Clerk \\
\hline Gillespie, Samuel & Private & Not available & Down & November 1814 & Weaver \\
\hline $\begin{array}{l}\text { Gleson / Glissane, } \\
\text { David }\end{array}$ & Private & 23 & Cork & September 1810 & Butcher \\
\hline Gorman, William & Private & 24 & Antrim & March 1810 & Baker \\
\hline Gormley, Hugh & Private & 16 & Derry & April 1814 & Labourer \\
\hline Graham, Alexander & Private & 34 & Down & November 1810 & Bricklayer \\
\hline Gray, John & Private & 28 & Down & August 1811 & Sawyer [?] \\
\hline Gray, Thomas & Private & 34 & Derry & August 1808 & Nailer \\
\hline Gray, William & Private & 24 & Derry & May 1810 & Coppersmith \\
\hline Green, William & Private & 24 & Antrim & November 1809 & Weaver \\
\hline Gribben, John & Private & 24 & Antrim & May 1812 & Weaver \\
\hline Gwynn, George & Private & Not available & Tyrone & August 1812 & Labourer \\
\hline Hagan, Bernard & Private & 27 & Down & January 1808 & Weaver \\
\hline Hagan, James & Private & 26 & Antrim & July 1808 & Weaver \\
\hline Hailes / Hails, Henry & Private & Not available & Donegal & Not available & Labourer \\
\hline Hall, Francis & Private & 38 & Fermanagh & October 1804 & Carpenter \\
\hline Hall, Robert & Private & 28 & Monaghan & October 1807 & Labourer \\
\hline Hamill, Daniel & Private & 30 & Antrim & July 1808 & Labourer \\
\hline Hamill, John & Private & 22 & Antrim & April 1810 & Weaver \\
\hline Hamilton, William & Private & 22 & Antrim & May 1812 & Weaver \\
\hline
\end{tabular}




\begin{tabular}{|c|c|c|c|c|c|}
\hline Hanson, Joseph & Private & 30 & Derry & October 1807 & Labourer \\
\hline Harkness James & Private & 28 & Down & August 1807 & Weaver \\
\hline Harrison, Michael & Sergeant & 29 & Fermanagh & February 1812 & Labourer \\
\hline Hart, Michael & Corporal & 30 & Longford & November 1808 & Labourer \\
\hline Harvey, Patrick & Sergeant & 32 & Donegal & October 1813 & $\begin{array}{l}\text { Labourer } \\
\text { Shoemaker }\end{array}$ \\
\hline Healy / Healey, John & Private & 31 & Mayo & September 1811 & {$[?]$} \\
\hline Healy, James & Private & 26 & Kerry & October 1807 & Shoemaker \\
\hline Heavy, Patrick & Private & 30 & Longford & July 1811 & Labourer \\
\hline Henderson, Samuel & Private & 27 & Fermanagh & January 1810 & Labourer \\
\hline $\begin{array}{l}\text { Henery / Henory, John } \\
\text { Henesay / Hensey, }\end{array}$ & Private & 23 & Derry & July 1808 & Labourer \\
\hline $\begin{array}{l}\text { Henesay / Hensey, } \\
\text { Patrick }\end{array}$ & Private & 21 & Cork & January 1815 & Labourer \\
\hline Hill, George & Private & 28 & Antrim & July 1808 & Labourer \\
\hline Hobson, Francis & Sergeant & 25 & Meath & February 1815 & Weaver \\
\hline Hughes, Richard & Private & 22 & Dublin & July 1811 & Smith \\
\hline Hume, William & Corporal & 23 & Dublin & July 1811 & Gardener \\
\hline Irvine / Irvin, Hugh & Private & 24 & Armagh & July 1809 & Weaver \\
\hline Irvine / Irvin, John & Private & 27 & Antrim & March 1808 & Weaver \\
\hline Irvine, Christopher & & & & & \\
\hline [Christian?] & Private & 21 & Tyrone & December 1813 & Labourer \\
\hline Johnson / Johnston, & & & & & Cotton \\
\hline Samuel & Private & 22 & Down & June 1810 & Spinner \\
\hline Johnston, John & Sergeant & Not available & Tyrone & February 1800 & Labourer \\
\hline Kane, Jackson & Private & 30 & Derry & September 1807 & Labourer \\
\hline Kearns / Kerns, John & Private & 43 & Longford & August 1806 & Labourer \\
\hline Keefe, James & Corporal & Not available & Kildare & May 1812 & Labourer \\
\hline Kelly / Kelley, James & Private & 24 & Donegal & July 1811 & Labourer \\
\hline Kiernan, James & Private & 38 & Longford & October 1807 & Labourer \\
\hline Lamb, Richard & Private & 19 & Cork & February 1815 & Tailor \\
\hline Laughlin, Patrick & Private & Not available & Armagh & March 1807 & Weaver \\
\hline Laverty, Thomas & Private & 26 & Antrim & July 1809 & Weaver \\
\hline Leary, Patrick & Private & 20 & Cork & November 1814 & Labourer \\
\hline Levins, John & Private & 25 & Dublin & May 1811 & Labourer \\
\hline Lewis, James & Private & 15 & Tyrone & February 1810 & Weaver \\
\hline Lindsay, Alexander & Private & 29 & Tyrone & September 1809 & Weaver \\
\hline Madden, Dennis & Private & 35 & Armagh & August 1806 & Weaver \\
\hline Magin / McGin, John & Corporal & 22 & Down & August 1812 & Labourer \\
\hline Mahoney, James & Private & 27 & Limerick & November 1807 & Weaver \\
\hline Mallow, Isiah & Private & 23 & Armagh & October 1812 & Labourer \\
\hline Marshall, James & Private & 27 & Derry & July 1814 & Labourer \\
\hline Mason, Patrick & Private & 26 & Antrim & January 1810 & Servant \\
\hline Matthews, Patrick & Private & 43 & Meath & January 1812 & Labourer \\
\hline Matthews, Thomas & Private & 25 & Louth & December 1811 & Labourer \\
\hline Mawhiney / Mahwinny, & & & & & \\
\hline David & Private & 33 & Derry & January 1811 & Weaver \\
\hline McAnally / McNally, & & & & & \\
\hline Francis & Private & 34 & Derry & November 1808 & Weaver \\
\hline McCabe, James & Private & 27 & Monaghan & January 1807 & Labourer \\
\hline McCaffery, Hugh & Private & 35 & Tyrone & October 1809 & Weaver \\
\hline McCann, Edward & Private & 24 & Mayo & June 1811 & Weaver \\
\hline McCann, John & Private & Not available & Antrim & May 1812 & Weaver \\
\hline McCarroll, Peter & Private & 22 & Tyrone & August 1814 & Labourer \\
\hline McCluskey, Andrew & Sergeant & 26 & Antrim & January 1807 & Labourer \\
\hline
\end{tabular}




\begin{tabular}{|c|c|c|c|c|c|}
\hline McCluskey, Thomas & Private & 23 & Derry & December 1807 & Labourer \\
\hline McDermott, Hugh & Private & 30 & Tyrone & July 1811 & Labourer \\
\hline McDonald, William & Private & 22 & Antrim & January 1810 & Weaver \\
\hline McDougle / & & & & & \\
\hline McDougall, John & Private & 25 & Down & August 1808 & Weaver \\
\hline McElhair, Robert & Private & 23 & Derry & May 1812 & Weaver \\
\hline $\begin{array}{l}\text { McGarey / McGarry, } \\
\text { Malachy }\end{array}$ & Private & 28 & Longford & July 1811 & Weaver \\
\hline $\begin{array}{l}\text { McGee / Maghee, } \\
\text { James }\end{array}$ & Corporal & 30 & Donegal & December 1809 & Weaver \\
\hline $\begin{array}{l}\text { McGeough / McGough, } \\
\text { Patrick }\end{array}$ & $\begin{array}{l}\text { Either Sergeant } \\
\text { or Private }\end{array}$ & 18 & Mayo & February 1812 & Labourer \\
\hline McGeough, Patrick & $\begin{array}{l}\text { Either Sergeant } \\
\text { or Private }\end{array}$ & Not available & Monaghan & October 1807 & Cooper \\
\hline & Private & 29 & Leitrim & October 1807 & Labourer \\
\hline McGrady, James & Private & Not available & Donegal & December 1811 & Labourer \\
\hline McHugo, Richard & Corporal & 18 & Cork & February 1815 & Carpenter \\
\hline McKaffery, James & Private & 28 & Fermanagh & March 1812 & Labourer \\
\hline McKay, Samuel & Private & 26 & Derry & October 1807 & Weaver \\
\hline $\begin{array}{l}\text { McLaughlin / } \\
\text { McLoughlin. William }\end{array}$ & Private & 25 & Longford & September 1811 & Labourer \\
\hline McLaughlin, Samuel & Private & 27 & Derry & October 1807 & Weaver \\
\hline McLaughlin, William & Private & Not available & Derry & October 1807 & Labourer \\
\hline McLean, David & Private & 32 & Tyrone & February 1814 & Labourer \\
\hline McLean, John & Private & Not available & Monaghan & Not available & Labourer \\
\hline McLeary, Joseph & Sergeant & 26 & Derry & October 1807 & Weaver \\
\hline McManus, Michael & Sergeant & 27 & Fermanagh & November 1807 & Labourer \\
\hline $\begin{array}{l}\text { McMullen / McMullin, } \\
\text { John }\end{array}$ & ivate & 27 & Antrim & Apr & Weaver \\
\hline McNally, Charles & Private & 25 & Donegal & January 1811 & Labourer \\
\hline McNanny, John & Private & Not available & Derry & February 1808 & Nailer \\
\hline McQuade, Thomas & Private & 24 & Derry & April 1808 & Weaver \\
\hline McRonald, John & Private & 28 & Derry & October 1807 & Weaver \\
\hline McSorley, Bernard & Private & 24 & Tyrone & January 1812 & Labourer \\
\hline McSweeney, Michael & Corporal & 25 & Limerick & August 1810 & Baker \\
\hline McVey, John & Private & 27 & Armagh & October 1808 & Weaver \\
\hline Mills, Robert & Drummer & 23 & Antrim & April 1812 & Labourer \\
\hline Moore, John & Private & 28 & Antrim & August 1807 & Weaver \\
\hline $\begin{array}{l}\text { Mullen / Mullin, } \\
\text { Terence }\end{array}$ & Private & Not & Armagh & Octo & Weaver \\
\hline Mullen, Simon & Private & 31 & Monaghan & November 1807 & Weaver \\
\hline Murphy, James & Private & 26 & Louth & July 1807 & Tailor \\
\hline Murray, John & Private & 22 & Carlow & May 1812 & $\begin{array}{l}\text { Weaver } \\
\text { Shoemak }\end{array}$ \\
\hline Oats, Michael & Sergeant & 23 & Donegal & January 1812 & {$[?]$} \\
\hline O'Connor, Henry & Sergeant & 38 & Roscommon & May 1811 & Labourer \\
\hline O'Connor, Patrick & Private & 22 & Mayo & September 1813 & $\begin{array}{l}\text { Labourer } \\
\text { Cotton }\end{array}$ \\
\hline O'Hara, Robert & Private & $32[?]$ & Down & May 1807 & Spinner \\
\hline Parks / Parkes, George & Private & 37 & Louth & May 1812 & Slater [?] \\
\hline Pickett, William & Private & 28 & Derry & February 1809 & Labourer \\
\hline Purfield, Patrick & Sergeant & 29 & Dublin & September 1806 & Tanner \\
\hline Quinn / Quim, John & Corporal & Not available & Derry & Not available & Weaver \\
\hline
\end{tabular}




\begin{tabular}{|c|c|c|c|c|c|}
\hline Quinn / Quim, Thomas & Private & 25 & Donegal & June 1812 & Labourer \\
\hline Reaside, William & Private & 29 & Down & August 1808 & $\begin{array}{l}\text { Cooper } \\
\text { Cotton }\end{array}$ \\
\hline Reid, Francis & Private & 33 & Donegal & May 1807 & Spinner \\
\hline Ritchie, William & Private & 38 & Derry & May 1812 & Weaver \\
\hline Rock, Laurence / & & & & & \\
\hline Lawrence & Private & 31 & Cavan & September 1806 & Weaver \\
\hline Ross, James & Private & 28 & Armagh & February 1808 & Weaver \\
\hline Rourke, Daniel & Private & 32 & Clare & October 1807 & Labourer \\
\hline Rowan, Thomas & Private & 23 & Galway & August 1812 & Joiner \\
\hline Saye / Seay, Arthur & Corporal & 23 & Down & May 1812 & Weaver \\
\hline Scanlon, Patrick & Private & 22 & Dublin & October 1812 & Cork Cutter \\
\hline Scott, Fletcher & Private & 34 & Monaghan & October 1807 & Not available \\
\hline Sheridan, Patrick & Private & 23 & Meath & December 1811 & Labourer \\
\hline Shields, John & Private & 22 & Donegal & February 1811 & Labourer \\
\hline Slattery, Edward & Corporal & 34 & Limerick & October 1807 & Labourer \\
\hline Slye, Thomas & Private & 44 & Wexford & September 1806 & $\begin{array}{l}\text { Shoemaker } \\
\text { Cotton }\end{array}$ \\
\hline Smith, Daniel & Private & 31 & Westmeath & August 1807 & Spinner \\
\hline Stanley, Michael & Private & 25 & Derry & August 1810 & Labourer \\
\hline Stewart, Charles & Private & 32 & Armagh & August 1811 & Weaver \\
\hline Strawbridge, William & Private & 22 & Antrim & February 1810 & Bricklayer \\
\hline Strong, George & Sergeant & 22 & Fermanagh & February 1810 & Labourer \\
\hline Taylor, William & Private & 33 & Donegal & May 1812 & Weaver \\
\hline Tevelin, James & Private & 24 & Meath & September 1811 & Baker \\
\hline Thompson, John & Private & 25 & Tyrone & November 1808 & Weaver \\
\hline Thompson, Thomas & Private & 26 & Donegal & October 1807 & Labourer \\
\hline Tierney, John & Sergeant & 30 & Limerick & October 1808 & Draper \\
\hline Tookey / Tuckey, & & & & & \\
\hline Anthony & Private & 22 & Galway & December 1811 & Butcher \\
\hline Turley, Peter & Private & 25 & Armagh & March 1808 & Weaver \\
\hline Vaughan, David & Private & 22 & Cork & February 1815 & Labourer \\
\hline Wall, William & Private & 41 & Cork & October 1807 & Sadler \\
\hline Wallace, David & Sergeant & 22 & Derry & September 1808 & Weaver \\
\hline Walsh, Thomas & Private & 24 & Dublin & July 1811 & Labourer \\
\hline Watson, Michael & Private & 32 & Derry & November 1807 & Labourer \\
\hline Weir, Patrick & Private & 27 & Queen's & 1804 & Weaver \\
\hline White, Sampson & Private & 25 & Down & August 1813 & Weaver \\
\hline Williamson, George & Private & 24 & Fermanagh & January 1812 & Labourer \\
\hline Wilson, Robert & Corporal & 17 & Down & July 1813 & Labourer \\
\hline Wood, John & Corporal & 31 & Dublin & September 1810 & Weaver \\
\hline
\end{tabular}




\begin{tabular}{|c|c|c|c|c|c|}
\hline Name & Rank & Age & County & Enlisted & Trade \\
\hline Astier, John & Private & 19 & King's & March 1813 & Labourer \\
\hline Bannon, Daniel & Private & 25 & Cavan & December 1813 & Labourer \\
\hline Barber, Drew & Private & 25 & Antrim & September 1812 & Tailor \\
\hline $\begin{array}{l}\text { Barnes / Burnes, } \\
\text { Patrick }\end{array}$ & $\begin{array}{l}\text { Private } \\
\text { Paymaster }\end{array}$ & 35 & Carlow & May 1800 & Labourer \\
\hline Barton, John & Sgt & 34 & Tipperary & June 1801 & Clerk \\
\hline Beamish, John & Private & 25 & Cork & March 1809 & Labourer \\
\hline Beatty, William & Drummer & 16 & Kildare & September 1813 & $\begin{array}{l}\text { Labourer } \\
\text { Silk }\end{array}$ \\
\hline Benson, Henry & Private & 22 & Dublin & June 1812 & Weaver \\
\hline Bible, Francis & Private & 29 & Waterford & July 1808 & Carpenter \\
\hline $\begin{array}{l}\text { Bingham, Peter } \\
\text { Bowel / Bowell, }\end{array}$ & Sergeant & 27 & Dublin & March 1809 & Tailor \\
\hline Robert & Private & 25 & Wicklow & April 1803 & $\begin{array}{l}\text { Labourer } \\
\text { Not }\end{array}$ \\
\hline Bowles, John & Private & 21 & Cork & 1812 & available \\
\hline Boyd / Boyde, Robert & Private & 26 & Monaghan & December 1813 & Labourer \\
\hline Boyle, Neal / Neale & Private & 21 & Antrim & March 1812 & Weaver \\
\hline Bray, William & Private & 24 & Dublin & May 1809 & Labourer \\
\hline Brennan, Andrew & Private & 28 & Queen's & September 1806 & Weaver \\
\hline Brett / Britt, Patrick & Corporal & 20 & Sligo & May 1812 & Labourer \\
\hline Brophy, John & Private & 18 & Dublin & April 1813 & Labourer \\
\hline Browne, James & Private & 21 & Cavan & May 1812 & Labourer \\
\hline Bryan, Daniel & Private & 21 & Cork & June 1810 & Pipemaker \\
\hline Bryan, & & & & & \\
\hline Edward & Private & 27 & Queen's & September 1806 & Labourer \\
\hline Bryan, John & Private & 23 & Cork & June 1810 & Pipemaker \\
\hline Burke, John & Private & 26 & Roscommon & February 1812 & Labourer \\
\hline Cadden, Michael & Private & 23 & Dublin & August 1807 & $\begin{array}{l}\text { Weaver } \\
\text { Not }\end{array}$ \\
\hline Cahill, John & Private & 19 & Cavan & November 1813 & available \\
\hline Cain, James & Private & 22 & Dublin & August 1808 & Labourer \\
\hline Carr, Peter & Private & 24 & Down & January 1807 & Weaver \\
\hline Carson, George & Private & 20 & Cavan & January 1813 & Weaver \\
\hline Carson, Simon & Private & 31 & Longford & June 1804 & Weaver \\
\hline Carty, Owen & Private & 26 & Leitrim & December 1813 & Labourer \\
\hline Cavanagh, Lawrence & Private & 31 & Carlow & July 1813 & Labourer \\
\hline Clarke, Francis & Sergeant & 25 & Longford & May 1810 & Labourer \\
\hline $\begin{array}{l}\text { Coghran / Cockran, } \\
\text { James }\end{array}$ & Private & 20 & Leitrim & December 1813 & Labourer \\
\hline Collier, William & Private & 19 & Dublin & May 1812 & Not \\
\hline
\end{tabular}




\begin{tabular}{|c|c|c|c|c|c|}
\hline $\begin{array}{l}\text { Corcoran, James } \\
\text { Costello / Costillo }\end{array}$ & Private & 18 & Westmeath & May 1812 & Tailor \\
\hline Thomas & Private & 20 & Galway & March 1813 & Labourer \\
\hline Craig, William & Private & 23 & Cavan & December 1813 & Weaver \\
\hline Crowley, William & Private & 32 & Cork & September 1800 & Labourer \\
\hline Crozier, Robert & Private & 20 & Dublin & April 1814 & Labourer \\
\hline Dalton, Richard & Private & 20 & Kilkenny & March 1807 & Labourer \\
\hline Devlin, Henry & Private & 19 & Antrim & March 1812 & $\begin{array}{l}\text { Weaver } \\
\text { Not }\end{array}$ \\
\hline Doherty, John & Private & 19 & Cavan & January 1814 & available \\
\hline Donahue, Edward & Private & 21 & Meath & January 1812 & Labourer \\
\hline Donlon, Patrick & Private & 30 & Dublin & 1803 & Labourer \\
\hline Donnelly, John & Private & 26 & Kilkenny & October 1813 & Labourer \\
\hline Donovan, Jeremiah & Private & 20 & Cork & February 1810 & Labourer \\
\hline Dowling, Stephen & Drummer & 18 & Galway & June 1807 & Labourer \\
\hline Downey, James & Private & 20 & Fermanagh & December 1813 & Weaver \\
\hline Doyle, John & Private & 21 & Kildare & February 1809 & Labourer \\
\hline Drew, Nicholas & Drummer & 24 & Waterford & January 1806 & Labourer \\
\hline Duffy / Duffey, James & Sergeant & 34 & Longford & August 1802 & Labourer \\
\hline Dumphy, Michael & Private & 22 & Kilkenny & June 1807 & Butcher \\
\hline Dunbar, John & Corporal & 28 & Dublin & May 1813 & Labourer \\
\hline Dunne, Lawrence & Private & 27 & Dublin & June 1807 & Millwright \\
\hline Dunne, William & Private & 26 & Queen's & December 1813 & Labourer \\
\hline \multicolumn{6}{|l|}{ Dunsheath / } \\
\hline Dumheath, James & Private & 18 & Antrim & December 1810 & Labourer \\
\hline Eagan, Gilbert & Private & 17 & Westmeath & May 1813 & Labourer \\
\hline Elliott, George & Private & 30 & Dublin & March 1803 & Labourer \\
\hline Fagan, David & Sergeant & 22 & Meath & June 1808 & Labourer \\
\hline Fagan, Edward & Private & 35 & Westmeath & March 1801 & Labourer \\
\hline Farrell, Francis & Private & 31 & Clare & October 1814 & Servant \\
\hline Fitzsimmons, Daniel & Private & 26 & Dublin & August 1812 & Labourer \\
\hline Flatley, John & Private & 28 & Sligo & October 1811 & Labourer \\
\hline Forster, Thomas & Private & 22 & Armagh & July 1811 & Weaver \\
\hline \multicolumn{6}{|l|}{ Gildea / Gilder, } \\
\hline Michael & Private & 31 & Galway & September 1806 & Labourer \\
\hline Glynn, William & Sergeant & 28 & Galway & May 1809 & Labourer \\
\hline Gordon, Thomas & Private & 20 & Monaghan & December 1813 & Labourer \\
\hline \multicolumn{6}{|l|}{ Gormly / Gormley, } \\
\hline Thomas & Private & 23 & Monaghan & December 1813 & Carpenter \\
\hline Graham, Robert & Corporal & 22 & Monaghan & October 1813 & Labourer \\
\hline Grey, Richard & Private & 18 & Dublin & September 1813 & Weaver \\
\hline Grier, Patrick & Private & 28 & Monaghan & December 1813 & Weaver [?] \\
\hline Grimes, Samuel & Private & 20 & Antrim & April 1812 & Weaver \\
\hline Hall, Charles & Private & 19 & Fermanagh & July 1812 & Weaver \\
\hline Hall, John & Private & 21 & Tyrone & August 1811 & $\begin{array}{l}\text { Weaver } \\
\text { Not }\end{array}$ \\
\hline Halligan, Stephen & Private & 20 & Louth & December 1813 & available \\
\hline Hamilton, Francis & Private & 20 & Cavan & December 1813 & Labourer \\
\hline Hamilton, William & Private & 20 & Dublin & August 1813 & Labourer \\
\hline
\end{tabular}




\begin{tabular}{|c|c|c|c|c|c|}
\hline $\begin{array}{l}\text { Hannon, Thomas } \\
\text { Healy / Healey, }\end{array}$ & Private & 19 & Cork & November 1810 & $\begin{array}{l}\text { Silver } \\
\text { Plater }\end{array}$ \\
\hline Thomas & Private & 30 & Dublin & July 1803 & Labourer \\
\hline Hennesey, John & Private & 27 & Queen's & September 1806 & Labourer \\
\hline Henry, William & Corporal & 33 & Tyrone & January 1804 & Clerk \\
\hline Hindes / Hinds, James & Private & 19 & Louth & December 1813 & Labourer \\
\hline Hollant, John & Private & 19 & Cork & March 1815 & Labourer \\
\hline Howes, Timothy & Private & 37 & Cork & February 1803 & Labourer \\
\hline Hoy, Michael & Private & 25 & Dublin & February 1814 & Labourer \\
\hline Hozie, Paul & Private & 27 & Queen's & September 1806 & Miller \\
\hline $\begin{array}{l}\text { Huson / Huston, } \\
\text { Bovle }\end{array}$ & Private & 17 & Dublin & Sentemher 1813 & \\
\hline $\begin{array}{l}\text { Johnstone, Edgar } \\
\text { Kelly, Dominic / }\end{array}$ & Private & 26 & Dublin & December 1806 & Hosier \\
\hline Dominick & Private & 24 & Dublin & November 1812 & Baker \\
\hline Kennedy, James & Private & 21 & Dublin & April 1808 & Labourer \\
\hline Kennedy, John & Private & 34 & Waterford & July 1801 & Labourer \\
\hline Kerr, Henry & Private & 21 & Kilkenny & December 1810 & Labourer \\
\hline Kiernan, Michael & Private & 23 & Armagh & December 1813 & Labourer \\
\hline Kinnon / Kennon, & & & & & \\
\hline John & Private & 22 & Derry & April 1813 & Weaver \\
\hline Kirkwood, William & Private & 21 & Derry & October 1813 & Weaver \\
\hline Lawler, Daniel & Private & 30 & Carlow & May 1813 & Labourer \\
\hline Leonard, Patrick & Private & 24 & Kildare & September 1808 & Labourer \\
\hline Little, John & Private & 23 & Cavan & January 1814 & Labourer \\
\hline Mackle, Charles & Private & 24 & Derry & October 1813 & Weaver \\
\hline Magwood, John & Private & 25 & Monaghan & December 1813 & Weaver \\
\hline Martin, Robert & Private & 22 & Monaghan & December 1813 & Weaver \\
\hline McAffee, John & Private & 21 & Antrim & January 1811 & $\begin{array}{l}\text { Not } \\
\text { available } \\
\text { Cotton }\end{array}$ \\
\hline McCabe, Peter & Private & 24 & Meath & July 1807 & Spinner \\
\hline McCann, Terence & Private & 22 & Cavan [sic] & November 1813 & Labourer \\
\hline McCarroll, James & Private & 21 & Derry & August 1812 & Weaver \\
\hline McCarthy, David & Private & 28 & Cork & April 1805 & Labourer \\
\hline McCarthy, Jeremiah & Private & 20 & Cork & February 1815 & Weaver \\
\hline McCormick, William & Sergeant & 27 & Donegal & August 1805 & Labourer \\
\hline McDole, Smith & Private & 20 & Antrim & June 1813 & Weaver \\
\hline McDonald, Timothy & Private & 35 & Cork & March 1801 & Brazier \\
\hline McGowan, John & Sergeant & 39 & Fermanagh & October 1802 & Labourer \\
\hline McGurn, Michael & Private & 25 & Leitrim & December 1813 & Weaver \\
\hline McHood, Edward & Private & 26 & Down & January 1807 & Weaver \\
\hline McKenny / McKenry, & & & & & Not \\
\hline Patrick & Private & 32 & Tyrone & December 1814 & available \\
\hline McLaughlin, David & Private & 35 & Derry & March 1801 & Weaver \\
\hline McManus, Edward & Private & 25 & Armagh & December 1813 & Weaver \\
\hline McNamara, John & Private & 26 & Tyrone & June 1809 & Weaver \\
\hline McPhatridge / & & & & & \\
\hline McPhartridge, John & Private & 20 & Antrim & May 1813 & Weaver \\
\hline
\end{tabular}


McQuade / McQuard,

\begin{tabular}{|c|c|c|c|c|c|}
\hline James & Private & 22 & Fermanagh & April 1812 & Labourer \\
\hline $\begin{array}{l}\text { Medcalfe / Metcalfe, } \\
\text { Thomas }\end{array}$ & Drummer & 16 & Dublin & September 1813 & Labourer \\
\hline $\begin{array}{l}\text { Meighan / Mighan, } \\
\text { John }\end{array}$ & Private & 27 & Longford & September 1811 & Labourer \\
\hline Miles, Michael & Private & 22 & Dublin & September 1808 & Labourer \\
\hline Miller, Hugh & Corporal & 29 & Longford & December 1813 & Labourer \\
\hline Miller, William & Private & 21 & Cavan & December 1813 & Weaver \\
\hline Montgomery, James & Private & 23 & King's & June 1812 & Labourer \\
\hline Moore, Samuel & Private & 33 & Derry & October 1808 & Weaver \\
\hline Morris, Charles & Private & 19 & Monaghan & December 1813 & Labourer \\
\hline Morris, Matthew & Private & 36 & Louth & December 1813 & Labourer \\
\hline $\begin{array}{l}\text { Morrow, William } \\
\text { Mortimore / }\end{array}$ & Private & 21 & Cavan & January 1814 & Tailor \\
\hline Mortimer, Alexander & Private & 25 & Monaghan & December 1813 & Weaver \\
\hline Mulholland, Arthur & Private & 18 & Antrim & June 1812 & Labourer \\
\hline Mullins, James & Private & 30 & Fermanagh & December 1802 & $\begin{array}{l}\text { Labourer } \\
\text { Not }\end{array}$ \\
\hline Mullins, Thomas & Private & Not available & Fermanagh & Not available & available \\
\hline Murphy, Michael & Private & 20 & Wicklow & November 1813 & Labourer \\
\hline Murphy, Patrick & Corporal & 25 & Longford & May 1810 & Labourer \\
\hline Murray, John & Private & 19 & Cork & June 1811 & Labourer \\
\hline Neilly, John & Private & 27 & Tyrone & July 1813 & Weaver \\
\hline Nesbitt, John & Private & 21 & Leitrim & December 1813 & Weaver \\
\hline Nichols, James & Sergeant & 29 & Fermanagh & December 1813 & Weaver \\
\hline $\begin{array}{l}\text { Noonan, Timothy } \\
\text { Nowland, Denis / }\end{array}$ & Private & 19 & Cork & October 1810 & Tailor \\
\hline Dennis & Corporal & 20 & Carlow & July 1813 & Labourer \\
\hline Nowland, James & Corporal & 26 & Longford & June 1804 & Weaver \\
\hline O'Brien, Patrick & Sergeant & 27 & Longford & May 1810 & Labourer \\
\hline Peyton, John & Private & 22 & Leitrim & September 1811 & Labourer \\
\hline $\begin{array}{l}\text { Pougue / Pongue, } \\
\text { George }\end{array}$ & Private & 25 & Monaghan & December 1813 & Weaver \\
\hline Pritchard, Richard & Corporal & 27 & Dublin & January 1803 & Labourer \\
\hline Pritchard, William & Private & 19 & Fermanagh & December 1811 & Sawyer \\
\hline Ramsay, William & Corporal & 31 & Fermanagh & February 1804 & Labourer \\
\hline Rea, James & Private & 23 & Antrim & August 1810 & Weaver \\
\hline Reed / Reid, Joseph & Private & 21 & Antrim & December 1813 & Weaver \\
\hline Reid / Reed, Samuel & Private & 20 & Cavan & October 1813 & Weaver \\
\hline Reilly, John & Private & 20 & Dublin & April 1813 & Labourer \\
\hline Reilly, Miles & Private & 21 & Cavan & January 1814 & Labourer \\
\hline Richardson, George & Corporal & 28 & Dublin & October 1802 & Labourer \\
\hline Rodgers, John & Private & 19 & Tyrone & June 1813 & Weaver \\
\hline Rooney, John & Private & 28 & Monaghan & January 1814 & Weaver \\
\hline $\begin{array}{l}\text { Rowen / Rowan, } \\
\text { Stephen } \\
\text { Rutherford, Joseph / }\end{array}$ & Private & 20 & Monaghan & December 1813 & Sawyer \\
\hline Joshua & Private & 29 & Monaghan & December 1813 & Weaver \\
\hline Sanders / Saunders, & Private & 23 & Galway & June 1807 & Labou \\
\hline
\end{tabular}


Thomas

\begin{tabular}{|c|c|c|c|c|c|}
\hline Savage, Richard & Private & 17 & Antrim & August 1813 & Weaver \\
\hline Seery, Patrick & Sergeant & 24 & Longford & August 1810 & Weaver \\
\hline Shanklin, Andrew & Corporal & 37 & Donegal & January 1803 & Weaver \\
\hline Shannon, Samuel & Private & 21 & Antrim & April 1812 & Weaver \\
\hline Shea, Luke & Private & 29 & Queen's & August 1810 & Labourer \\
\hline Sheridan, John & Private & 25 & Clare & March 1815 & Labourer \\
\hline Sherry, William & Private & 21 & Armagh & May 1812 & Labourer \\
\hline Sinnett / Sinnott, & & & & & \\
\hline Moses & Private & 28 & Dublin & July 1808 & Carpenter \\
\hline Skelling, William & Private & 18 & Meath & March 1814 & Labourer \\
\hline Smith, James & Private & 20 & Monaghan & December 1813 & Labourer \\
\hline Stevenson, Robert & Sergeant & 29 & Down & January 1807 & Labourer \\
\hline Stuart, Thomas & Private & 22 & Cavan & December 1813 & Weaver \\
\hline Sullivan, James & Private & 21 & Cork & November 1810 & Carpenter \\
\hline Sullivan, Patrick & Private & 24 & Cork & January 1807 & Labourer \\
\hline Sweeney, John & Private & 35 & Kerry & May 1805 & $\begin{array}{l}\text { Labourer } \\
\text { Not }\end{array}$ \\
\hline Switzer, Christopher & Sergeant & 34 & Tipperary & September 1806 & available \\
\hline Thornton, Patrick & Private & 20 & Louth & December 1813 & Labourer \\
\hline Toole, Patrick & Private & 34 & Galway & September 1806 & Labourer \\
\hline Turner, William & Corporal & 21 & Derry & October 1813 & Labourer \\
\hline Vereker, Denis & Private & 22 & Limerick & September 1808 & Labourer \\
\hline Wales, Thomas & Private & 19 & Monaghan & December 1813 & Labourer \\
\hline Willis, William & Private & 22 & Meath & June 1807 & Weaver \\
\hline Winters, Patrick & Private & 20 & Monaghan & December 1813 & Weaver \\
\hline Woods, Peter & Private & 22 & Galway & August 1807 & Weaver \\
\hline
\end{tabular}




\section{REFERENCES}

${ }^{1}$ Andrew O'Reilly, The Irish abroad and at home; at the court and in the camp (New York, 1856), p. 213-4.

2 From the approximate duration of Napoleon's return to power in 1815. The term appears to have been in common use in both French and English from relatively soon after the episode. Frenchman Fleury de Chaboulon's memoirs, for example, were first published in 1820 and used it as their title. See Fleury de Chaboulon, Les cent jours (London, 1820).

3 Jeremy Black, The battle of Waterloo: a new history (London, 2010), and Peter Snow, To war with Wellington: from the Peninsula to Waterloo (London, 2010).

${ }^{4}$ For one recent, though arguably worthwhile, example from a multitude of biographies of Wellington, see Richard Holmes, Wellington: the Iron Duke (London, 2003).

${ }^{5}$ See, for example, Martin Cassidy, Marching with Wellington: with the Enniskillings [sic] through the Peninsula to Waterloo (London, 2003); as well as Michael D. Fox, The green square: H.M. $27^{\text {th }}$ (Inniskilling) Regiment of Foot at the battle of Waterloo (Kent, 1990).

${ }^{6}$ Charles Cadell, Narrative of the campaigns of the Twenty-Eighth Regiment since their return from Egypt in 1802 (London, 1835), pp 228-30. The author of these memoirs, Scotsman Captain Charles Cadell of the $28^{\text {th }}$ Foot, noted that his battalion had unfortunate recent form in this regard. Another soldier had suffered an identical fate while attempting to board a transport at Monkstown, County Cork, the previous year.

${ }^{7}$ Edward Creasy, The fifteen decisive battles of the world: from Marathon to Waterloo (London, 1869). John William Fortescue, $A$ history of the British army (London, 1899).

${ }^{8}$ Alun G. Jones, Lord Chalfont (ed.), Waterloo: battle of three armies (London, 1979).

${ }^{9}$ Mark Adkin, The Waterloo companion: the complete guide to history's most famous land battle (London, 2001).

${ }^{10}$ Andrew Uffindel and Michael Corum, On the fields of glory: the battlefields of the 1815 campaign (London, 2002). Alessandro Barbero, The battle: a new history of the battle of Waterloo (London, 2005).

${ }^{11}$ See, in particular, Peter Hofschröer, 1815: the Waterloo campaign: Wellington, his German allies and the battles of Ligny and Quatre Bras (London, 1998).

12 Waterloo 200, 'Home' (http://www.waterloo200.org/home.html) (23 Jul. 2011).

${ }^{13}$ Harry Ross-Lewin, With "The Thirty-Second" in the Peninsular and other campaigns, (Dublin, 1904), pp 282-3.

${ }^{14}$ For a detailed account of Napoleon's remarkable journey from Elba to Paris, see Mark Adkin, The Waterloo companion: the complete guide to history's most famous land battle (London 2001), pp 11-20

${ }^{15}$ Alessandro Barbero, The battle: a history of the battle of Waterloo (London, 2005), p. 2.

${ }^{16}$ Ibid.

${ }^{17}$ As with many points of statistical data relating to Waterloo, significant discrepancy exists between secondary sources regarding the precise strengths of the opposing armies in 1815. For the sake of consistency, all of the figures for military strengths and casualties in this paper have been drawn from Mark Adkin's reasonably recent and authoritative reference work on the campaign. See Mark Adkin, The Waterloo companion: the complete guide to history's most famous land battle (London 2001), pp 37-74.

${ }_{18}$ Geoffrey Wooten, Waterloo 1815: birth of modern Europe (Oxford, 1999), p. 45

${ }^{19}$ Alessandro Barbero, The battle: a history of the battle of Waterloo (London, 2005), pp 421-22.

20 See Gregor Dallas, 1815: the roads to Waterloo (London, 1996), p. 368.

${ }^{21}$ Freeman's Journal, 12 Apr. 1815.

22 Freeman's Journal, 9 May 1815.

23 Ibid.

${ }^{24}$ National Library of Ireland [hereafter NLI] MS 27, 796 (5), letter from James Grattan to Colonel Fitzgerald, March 1815.

${ }^{25}$ The somewhat misnamed War of 1812 actually lasted until early 1815, when the Treaty of Ghent was ratified between Britain and the United States. Irish general Sir Edward Pakenham became one of the war's most highprofile fatalities at the battle of New Orleans in January 1815. For a full account of the conflict, see Carl Benn, The War of 1812 (Oxford, 2002).

${ }^{26}$ Edwin Griffith and Frederick Phillips, From Corunna to Waterloo: the letters and journals of two Napoleonic hussars, 1801-1816, ed. Gareth Glover (London, 2007), p. 236. On arrival in Ireland, however, Griffith was slightly mollified; acknowledging that parts of Dublin were 'particularly handsome, [and] Dame Street, Westmorland [sic] and Sackville are superior to any I think in London'.

${ }^{27}$ Donald Maclean, 'A highland soldier's manuscript' in Celtic Review, x, no. 40 (June 1916), pp 289-

311. A Scottish soldier of the $42^{\text {nd }}$ Highlanders, Private Gunn's fascinating unpublished account covers his active service in the Peninsula, Holland and at Waterloo, as well as his impressions of garrison life in Ireland in 1814-15.

${ }^{28}$ National Archives, Kew [hereafter NA (Kew)] WO 97/576/129, service documents, David Carroll, $42^{\text {nd }}$ Foot $1814-$

37. Carroll was wounded in the right leg at Waterloo, but recovered sufficiently to carve out a relatively successful post-war career in the army; not being discharged until May 1837 when he had reached the rank of corporal. The 
regimental board of the $42^{\text {nd }}$ Highlanders that discharged him at Edinburgh Castle that year described him as '... a good and efficient soldier, seldom in hospital, trustworthy and sober'. The Irish veteran appears to have settled in Scotland after leaving the military; the Irish Times noting his death at Dalkeith, Midlothian, in May 1864. See Irish Times, 25 May 1864.

${ }^{29} \mathrm{NA}(\mathrm{Kew})$ WO 25/356, description book, 27 $7^{\text {th }}$ Foot, 1816-29.

${ }^{30} \mathrm{NA}$ (Kew) WO 25/314, description book, $3^{\text {rd }}$ Battalion, $1^{\text {st }}$ Foot, 1812-16. Buckley's military career proved to be very short-lived indeed, as he was discharged the same year; almost certainly due to injuries received during the Waterloo campaign. See NA (Kew) WO 97/221/12, service documents, Denis Buckley, $1^{\text {st }}$ Foot 1815.

${ }^{31}$ Edward Costello, The adventures of a soldier (London, 1852), p. 2. Born in Mountmellick, Queen's County, in 1788, Costello enlisted into the $95^{\text {th }}$ Rifles as a private soldier in 1807 and later saw extensive service in the Peninsula and at Waterloo. His memoir is a valuable record of this period, not simply as one of comparatively few Irish military accounts, but due also to their coming from an enlisted man - rare in a period when the average British private soldier was illiterate. Officers' memoirs and journals tend to dominate instead. At least one other purported account of the Waterloo campaign written by an ordinary Irish soldier exists: the autobiography of County Louth man Private Charles O'Neil of the $28^{\text {th }}$ Foot. See Charles O'Neil, The military adventures of Charles O'Neil (Worcester, 1851). However, O'Neil's work is distinctly unreliable as a primary source. By his own admission, he was a something of a bad apple as a soldier, with a substantial record of desertion and insubordination, and his account is somewhat prone to exaggeration and inaccuracy. Much more damningly, recent research has cast doubt on his claim to have been present during the Waterloo campaign at all. See John Duncan Ellis, 'Recruitment and promotion in the Napoleonic British army: a study of the $28^{\text {th }}$ (North Gloucestershire) Regiment of Foot, an English regiment at Waterloo' (B.A. dissertation, Cheltenham and Gloucester College of Higher Education, 1999).

32 Donald Maclean, 'A highland soldier's manuscript' in Celtic Review, x, no. 40 (June 1916), pp 289- 311.

${ }^{33}$ Charles Cadell, Narrative of the campaigns of the Twenty-Eighth Regiment since their return from Egypt in 1802 (London, 1835), pp 229-30.

${ }^{34}$ Edwin Griffith and Frederick Phillips, From Corunna to Waterloo: the letters and journals of two Napoleonic hussars, 1801-1816, ed. Gareth Glover (London, 2007), p. 248.

$35 \mathrm{Ibid}$. Sadly, Griffith would never visit the County Kerry town, as he was killed in action at Waterloo on 18 June 1815.

${ }^{36}$ NA (Kew) WO 25/314, description book, $3^{\text {rd }}$ Battalion, $1^{\text {st }}$ Foot $1812-16$.

${ }^{37}$ NA (Kew) WO 25/366, description book, $32^{\text {nd }}$ Foot $1815-26$.

${ }^{38}$ National Archives of Scotland MS GD 139/369/24, letter from Captain John Sinclair to Eliza Sinclair, 28 March 1815. Sinclair's ill-feeling about the coming campaign was well-founded, as he was mortally wounded at the battle of Quatre Bras on 16 June 1815, dying the following day. See Charles Dalton, The Waterloo roll call (London, 1904), p. 191.

${ }^{39}$ Edwin Griffith and Frederick Phillips, From Corunna to Waterloo: the letters and journals of two Napoleonic hussars, 1801-1816, ed. Gareth Glover (London, 2007), p. 249.

40 Freeman's Journal, 6 Apr. 1815.

${ }^{41}$ Freeman's Journal, 6 May 1815. See also Harry Ross-Lewin, With "The Thirty-Second" in the Peninsular and other campaigns, ed. John Wardell (Dublin, 1904), p. 246.

42 Namely English, French, German and Dutch / Flemish.

${ }^{43}$ From approximately 1807, Polish light cavalrymen had served in Napoleon's army, ultimately as part of the Imperial Guard, and were represented at its final campaign in 1815. A wider pattern of Polish service in the French military of the Napoleonic period also existed. See Ronald Pawly, Napoleon's Polish lancers of the Imperial Guard (Oxford, 2007); as well as Otto von Pivka, Napoleon's Polish troops (Oxford, 1974).

${ }^{44}$ See George Martinez, 'Semper et Ubique Fidelis' in Nathalie Genet-Rouffiac and David Murphy (eds), FrancoIrish military connections, 1590-1945 (Dublin, 2009), pp 139-49.

${ }^{45}$ See Nicholas Dunne-Lynch, 'The Irish Legion of Napoleon, 1803-15' in Nathalie Genet-Rouffiac and David Murphy (eds), Franco-Irish military connections, 1590-1945 (Dublin, 2009), pp 189-218.

${ }^{46}$ George Martinez, 'Semper et Ubique Fidelis' in Nathalie Genet-Rouffiac and David Murphy(eds), Franco-Irish military connections, 1590-1945 (Dublin, 2009), p. 141.

${ }^{47}$ Benjamin Robert Haydon, Life of Benjamin Robert Haydon, historical painter, from his autobiography and journals, ed. Tom Taylor (2 vols, London, 1853), i, pp 312-13. The conversation between Haydon and Hodgson appears to have occurred due to the former's employment of soldiers as life models for his paintings. While the story cannot be confirmed one way or the other, it is interesting to note that a Corporal William Hodgson of the $2^{\text {nd }}$ Life Guards is indeed recorded as having received the Waterloo Medal for his participation in the campaign. See Christopher Buckland, The Waterloo Medal roll (Dallington, 2001), p. 9.

${ }^{48}$ Anonymous, 'A tradition of Waterloo' in Irish Sword, viii, no. 31 (1967), p. 140. The anecdote ends on a relatively upbeat note, with the reconciled Irish brothers flipping a coin before deciding to return together to Wellington's lines.

${ }^{49}$ William M. Thackeray, The luck of Barry Lyndon: a romance of the last century (2 vols, London, 1853). The eponymous protagonist of Thackeray's novel is an Irishman who, amongst other adventures, is forcibly enlisted 
into the Prussian army after deserting from British service during the Seven Years' War of the mid-eighteenth century. His travails are undoubtedly better known to modern audiences through Stanley Kubrick's eponymous 1975 film adaptation of the work.

${ }^{50}$ As part of a recent assessment of the same Irish Legion of Napoleon mentioned above, Nicholas Dunne-Lynch has noted that unit's incorporation of a contingent of Prussian prisoners of war after the battle of Jena-Auerstedt in 1806; among whom were a number of Irishmen of this sort. See Nicholas Dunne-Lynch, 'The Irish Legion of Napoleon, 1803-15' in Nathalie Genet-Rouffiac and David Murphy (eds), Franco-Irish military connections, 15901945 (Dublin, 2009), pp 192-3.

${ }^{51}$ In his examination of Irish involvement with Nazi Germany's Waffen SS during the Second World War, Terence O'Reilly provides an excellent overview of what relatively few military connections have existed between Ireland and Germany since the eighteenth century. See Terence O'Reilly, Hitler's Irishmen (Cork, 2008), pp 7-29.

${ }^{52}$ A study of a sample group of 44 Waterloo campaign veterans from the $1^{\text {st }}$ Battalion of the $27^{\text {th }}$ (Inniskilling) Foot, for example, found that 41 soldiers (around 93 per cent) were indeed Irish. See Peter Molloy, 'An Irish battalion at Waterloo: $1^{\text {st }}$ Battalion, $27^{\text {th }}$ (Inniskilling) Foot and the human reality of Napoleonic warfare' (B.A. dissertation, University College Dublin, 2010).

${ }^{53}$ For an introductory - though not definitive - overview of Irish service in the British army of the Peninsular War, see Mike Chappell, Wellington's Peninsular regiments (1): the Irish (Oxford, 2003).

${ }^{54} \mathrm{He}$ commended the battalion for attacking 'in the most gallant manner'. See Arthur Wellesley $\left(1^{\text {st }}\right.$ Duke of Wellington), The despatches of Field Marshal the Duke of Wellington during his various campaigns from 1799 to 1818, ed. John Gurwood (12 vols, London, 1836) vi, p. 446.

${ }^{55}$ Henry Harris, The Royal Irish Fusiliers (the $87^{\text {th }}$ and $89^{\text {th }}$ Regiments of Foot) (London, 1972), pp $31-6$.

56 Of these three units, two were affiliated to the town of Enniskillen, County Fermanagh - sometimes claimed as being unique in British military history as the only town or city in the British Isles to lend its name to two separate regiments to the British army. See George Stevens, A history of the Royal Inniskilling Fusiliers (Enniskillen, 1993), p. 1. It should be noted that usage of the slightly corrupted spellings 'Inniskilling' or 'Inniskillings' is deliberate throughout this thesis when referring to these regiments and their personnel, as this is the form that was historically preferred by both units

57 In the spring and summer of 1815 , for example, the $1^{\text {st }}$ Battalion of the $87^{\text {th }}$ Foot was in India, while the regiment's $2^{\text {nd }}$ Battalion was on garrison duty on the island of Guernsey. See Henry Harris, The Royal Irish Fusiliers (the $87^{\text {th }}$ and $89^{\text {th }}$ Regiments of Foot) (London, 1972), p. 41

58 In his worthwhile History of the Irish soldier (1987), to reference one example, A.E.C. Bredin devoted the overwhelming majority of his analysis of the experiences of his countrymen at Waterloo to examining those few units present with Irish identities. Like a number of authors before and after him, Bredin also failed to identify the $18^{\text {th }}$ Hussars as an Irish regiment. See A.E.C. Bredin, A history of the Irish soldier (Belfast, 1987), p. 270. The omission of this unit from many existing overviews of Irish involvement in the Waterloo campaign may very well be due to the fact that it did not survive for long into the nineteenth century. The $18^{\text {th }}$ Hussars were disbanded in 1821 ; ironically, on foot of a general reduction in the strength of the British army due to the lasting peace that had followed victory in 1815 and the end of the Napoleonic Wars.

${ }^{59}$ Edward M. Spiers, 'Army organisation and society in the nineteenth century' in Thomas Bartlett and Keith Jeffery (eds), A military history of Ireland (Cambridge, 1996), p. 335.

${ }^{60}$ Richard Holmes, Redcoat: the British soldier in the age of horse and musket (London, 2002), p. 55.

${ }^{61}$ Richard Holmes, Redcoat: the British soldier in the age of horse and musket (London, 2002), pp 55- 6.

62 In both cases a list of confirmed Irish veterans of the Waterloo campaign was obtained by studying the relevant description book for each battalion, held at the National Archives in Kew (respectively WO 25/314, description book, $3^{\text {rd }}$ Battalion, $1^{\text {st }}$ Foot, 1812-16; and WO 25/366, description book, $32^{\text {nd }}$ Foot 1815-26). These documents effectively represent a sort of periodic unit census, and unlike the muster rolls and pay lists which formed the more regular human resources records of contemporary British army units, they feature relatively detailed biographical information for individual soldiers.

Crucially, this includes places of birth, as well as additional personal data. Every individual Irish soldier thus identified was checked against the regimental lists of recipients of the Waterloo Medal contained in Christopher Buckland's reference work The Waterloo Medal roll (Dallington, 2001), in order to confirm their service during the campaign. The full list of Irish personnel in each battalion is appended below.

${ }^{63}$ From 1782, most British infantry regiments bore - in addition to their numerical designations - a regional affiliation in parentheses. Thus, in 1815 the 1st Foot was properly the 1st Foot (Royal Scots), the 32nd Foot the 32nd (Cornwall) Foot, and so on. In practice, the theoretical link that a regiment might have to a given recruiting area was no guarantee at all that its human composition would reflect the association, as the high numbers of Irish personnel in both of the battalions studied for this paper suggest. For the sake of simplicity, numerical titles only have been used throughout this paper when referring to British units; save for when it is particularly relevant to highlight a territorial link (as in the cases of the Irish units present during the campaign). The use of numerical titles alone is also the practice that appears most frequently in primary British sources from the Napoleonic era; whether official military records or personal accounts. 
64 Martin Aaron, '2 ${ }^{\text {nd }}$ Battalion 69 ${ }^{\text {th }}$ (South Lincolnshire) Foot during the Waterloo Campaign' (http://www.napoleonseries.org/military/organization/Britain/Infantry/c_2-69Waterloo.html\#_ftn2) (14 Aug. 2011).

65 The more familiar spelling 'Wellesley' was not adopted by the Irish family - including the future Duke of Wellington - until the very end of the eighteenth century. See Elizabeth Longford, Wellington: the years of the sword (London, 1969), pp 53-4.

${ }^{66}$ Richard Holmes, Wellington: the Iron Duke (London, 2003), p. 21.

${ }^{67}$ But for a twist of fate, one of the most senior of these Irish soldiers would have been General Sir Galbraith Lowry Cole, Dublin-born scion of an influential County Fermanagh family and a highly experienced soldier who had commanded the $4^{\text {th }}$ British Division for much of the Peninsular War. In 1815, Lowry Cole was scheduled to command the $6^{\text {th }}$ British Division in Wellington's army. In a spectacular instance of bad timing, however, he was in England getting married in mid-June that year and so missed Napoleon's surprise invasion of Belgium and the ensuing campaign entirely. One other particularly senior subordinate of Wellington's at Waterloo, his adjutant general Major General Sir Edward Barnes, has sometimes been referred to in secondary sources as being of Irish extraction, but it is not at all clear if he was actually born in the country. See Charles Dalton, The Waterloo roll call (London, 1904), p. 29.

${ }^{68}$ Dictionary of Irish biography. See also James Graves and John G. Augustus, The history, architecture and antiquities of the Cathedral Church of St Canice, Kilkenny (Dublin, 1857), p. 332.

${ }^{69}$ Dictionary of Irish biography. One of Ponsonby's three regiments was Irish - the $6^{\text {th }}$ (Inniskilling) Dragoons. The remaining two represented - respectively - the English and Scottish portions of the brigade: the $1^{\text {st }}$ (Royal) Dragoons and the $2^{\text {nd }}$ (Royal North British) Dragoons.

${ }^{70}$ Dictionary of Irish biography. Vandeleur's family origins were apparently Dutch, and one source had suggested that the Irish general spotted his family's crest above the door of his billet on the evening of the battle of Waterloo. See Robert Staveley, Waterloo campaign: sketches and anecdotes (Dublin, 1896), pp 10-11. The archives of Trinity College Dublin hold a collection of letters written by Vandeleur to his wife during the Waterloo campaign (MS 4022a). However, these are largely concerned with personal and domestic issues, and make little significant mention of military events.

${ }^{71}$ Gentleman's Magazine, xliii (Jan.-Jun. 1855), p. 310.

72 Thomas Carter, Historical record of the Forty-Fourth or the East Essex Regiment of Foot (London, 1864), p. 96.

${ }^{73}$ Oxford dictionary of national biography. See also Gentleman's Magazine, xliii (Jan.-Jun. 1855), p. 309.

${ }^{74}$ Raymond Henry Raymond Smythies, Historical records of the $40^{\text {th }}$ ( $2^{\text {nd }}$ Somersetshire) Regiment, now $1^{\text {st }}$ Battalion The Prince of Wales's Volunteers (South Lancashire Regiment), from its formation, in 1717, to 1893 (Devonport, 1894), p. 568. The Irishman was buried near to where he fell on the battlefield of Waterloo

75 One of the most intriguing backgrounds of any junior officer with Irish connections to see service during the Waterloo campaign was that of Lieutenant John Molloy (no relation to author), a subaltern in the $1^{\text {st }}$ Battalion of the $95^{\text {th }}$ Rifles. Seemingly raised in England by an Irish family, Molloy has been claimed to have been one of very few men to see service at the battles of both Trafalgar and Waterloo - two of the most pivotal engagements of the Napoleonic Wars. Speculation has also existed that Molloy was by birth an illegitimate son of Prince Frederick, Duke of York and son of King George III. One recent assessment of Molloy's life and career has suggested peeress Susanna Hussey, Countess of Tyrconnel, as a possible candidate for his natural mother. See Alexandra Hasluck, Portrait with background: a life of Georgiana Molloy (Melbourne, 1955), pp 1-12; as well as Gil Hardwick, 'The Irish R.M.: Capt. John Molloy of the Vasse' in R.H.W. Reece (ed.), The Irish in western Australia (Perth, 2000), pp 1-20. Molloy has been a particular subject of study in Australia, where he served as a colonial administrator later on in the nineteenth century.

${ }^{76}$ Harry Ross-Lewin, With "The Thirty-Second" in the Peninsular and other campaigns, ed. John Wardell (Dublin, 1904), pp 261-2. These three men were Captains Jaques Boyse (or Boyce), Thomas Cassan and Edward Whitty. See also George Clayton Swiney, Historical records of the $32^{\text {nd }}$ (Cornwall) Light Infantry, now the $1^{\text {st }}$ Battalion, Duke of Cornwall's L.I., from the formation of the regiment in 1702 down to 1893 (London, 1893), pp 114-8. Another Irish officer of the battalion in June 1815 not mentioned directly by Ross-Lewin in his account of the campaign was Lieutenant Samuel Hill Lawrence of County Cork. Lawrence's son, also called Samuel Hill, would earn the Victoria Cross in 1857 for his gallantry as an officer of the $32^{\text {nd }}$ Foot during the Indian Mutiny. See Richard Doherty and David Truesdale, Irish winners of the Victoria Cross (Dublin, 2000) p. 49.

${ }^{77}$ Charles Dalton, The Waterloo roll call (London, 1904), pp 175-8. London's National Army Museum holds a graphic practical relic of Irish involvement in the Waterloo campaign in the form of a coatee which belonged to Lieutenant Henry Anderson of County Kilkenny, an officer of this battalion. The garment still bears the impact marks of the French musket ball which severely wounded Anderson at the climax of the battle of Waterloo. See Susan M. Pearce, 'Objects as meaning; or narrating the past' in Susan M. Pearce (ed.), Interpreting objects and collections (London, 1994), pp 19-29.

${ }^{78}$ Gentleman's Magazine, vii (Jan.-Jun. 1837), p. 432. See also C.R.B. Barrett, History of the XIII Hussars (London, 1911).

${ }^{79}$ Charles Dalton, The Waterloo roll call (London, 1904), p. 57. A number of letters written by Fitzgerald to his wife while on campaign with the British army during the Napoleonic Wars survive in the National Library of Ireland. 
Regrettably, however, none deal with his experiences during the Waterloo campaign. See NLI MS 27, 843 (1-2), Colonel Edward Thomas Fitzgerald letters.

${ }^{80}$ Charles Dalton, The Waterloo roll call (London, 1904), pp 19-26.

${ }^{81}$ For a comprehensive overview of civilian interaction of this sort with the British army of the Napoleonic era, see F.C.G. Page, Following the drum: women in Wellington's wars (London, 1986). See also Richard Holmes, Redcoat: the British soldier in the age of horse and musket (London, 2002), pp 292-306.

82 When the $1^{\text {st }}$ Battalion of the $42^{\text {nd }}$ Highlanders left Ireland to join Wellington's army, for example, each of the battalion's ten companies was permitted to have only four women accompany it. Each woman was entitled to half-rations daily. See F.C.G. Page, Following the drum: women in Wellington's wars (London, 1986), p. 26.

${ }^{83}$ Mark Urban has described the case of a Corporal George Pitt of the $1^{\text {st }}$ Battalion of the $95^{\text {th }}$ Rifles, who consciously chose to be court-martialed rather than leave his wife behind as ordered when the battalion took ship for Belgium at Dover in April 1815. Sentenced to receive 300 lashes for his disobedience, Pitt's punishment was eventually commuted after 100 lashes by the battalion's Irish commanding officer, Lieutenant Colonel Sir Andrew Barnard. See Mark Urban, Rifles: six years with Wellington's legendary sharpshooters (London, 2003), p. 261.

${ }^{84}$ Cavalié Mercer, Journal of the Waterloo campaign (2 vols, London, 1870), i, pp 15-6.

${ }^{85}$ Royal Welch Fusiliers Museum, 'Jenny Jones, a Regimental Wife'

(http://www.rwfmuseum.org.uk/nb.html\#Jenny\%20Jones,\%20a\%20Regimental\%20Wife) (26 Jul. 2011). See also Martyn Griffiths, 'The story of Jenny Jones of Talyllyn' (http://www.martyngriff.co.uk/jenny/index.htm) (26 Jul. 2011). Returning moderately wounded to the rear after the battle of Quatre Bras, Corporal Edward Costello witnessed groups of camp followers: '... in great numbers, making inquiries about their husbands, friends, \&c. The crowds of carts, horses \&c., which thickly thronged the roadway, were greeted on all sides by anxious faces and earnest inquiries'. See Edward Costello, The adventures of a soldier (London, 1852), p. 194.

${ }^{86}$ Although the story has since appeared frequently in Waterloo literature, one of the earliest verifiable references to it comes very soon after the campaign, in an 1817 eyewitness account by a Scottish woman, Charlotte Eaton, who had been present in Belgium during the fighting of June 1815. Eaton claimed to have personally encountered the woman who had rescued her husband in this manner; noting the wounded soldier's regiment as the $27^{\text {th }}$ Foot but not providing a surname for the couple. See Charlotte Eaton, Narrative of a residence in Belgium during the campaign of 1815; and of a visit to the field of Waterloo (London, 1817), p. 317. See also Christopher Kelly, A full and circumstantial account of the memorable battle of Waterloo (London, 1817), p. 99; and William Copeland Trimble, The historical record of the $27^{\text {th }}$ Inniskilling Regiment, from the period of its institution as a volunteer corps to the present time (London, 1876), pp 73-4. Certainly, three privates named McMullen (Peter, John and William) received the Waterloo Medal for their service with the $1^{\text {st }}$ Battalion of the $27^{\text {th }}$ Foot during the campaign, lending some potential credence to the account. See Christopher Buckland, The Waterloo Medal roll (Dallington, 2001) pp 188-94.

${ }^{87} \mathrm{NA}(\mathrm{Kew})$ WO 25/314, description book, $3^{\text {rd }}$ Battalion, $1^{\text {st }}$ Foot $1812-16$.

${ }^{88}$ An astonishing number of secondary studies of the campaign, however brief, devote a line or two to the Irish battalion's ordeal at Waterloo. Allan Mallinson's recent general history of the British army, for example, notes that the unit lost '... 400 men... before firing a single musket'. See Allan Mallinson, The making of the British army: from the English Civil War to the War on Terror (London, 2009),p.

188. In his influential 1976 examination of the human experience of warfare, British military historian John Keegan assessed the experience of the battalion at some length. See John Keegan, The face of battle: a study of Agincourt, Waterloo and the Somme (London, 1976), pp 128-36.

${ }^{89}$ William Copeland Trimble, The historical record of the $27^{\text {th }}$ Inniskilling Regiment, from the period of its institution as a volunteer corps to the present time (London, 1876), pp 67-8.

${ }^{90}$ Quoted in H.T. Siborne, The Waterloo letters: accounts of the battle by British officers for its foremost historian (London, 2009), p. 379.

91 Mark Adkin, The Waterloo companion: the complete guide to history's most famous land battle (London, 2001), p. 44.

92 Lieutenant John Kincaid, $95^{\text {th }}$ Rifles; quoted in Andrew Uffindell and Michael Corum, On the fields of glory: the battlefields of the 1815 campaign (London, 1996), p. 127.

${ }_{93}$ Harry Ross-Lewin, With "The Thirty-Second" in the Peninsular and other campaigns, ed. John Wardell (Dublin, 1904), p. 276.

${ }^{94}$ Quite apart from historical study, Waterloo remains a cherished battle honour for the British Army's contemporary Royal Irish Regiment - ultimate successor, through a complex series of amalgamations, to the $27^{\text {th }}$ Foot of 1815. On 18 June 2011, Waterloo Day, the $1^{\text {st }}$ Battalion of that regiment marked its return from a demanding tour of Afghanistan with the awarding of campaign medals. At the close of the medal ceremony, the battalion was marched off the parade ground by its non-commissioned officers: a symbolic nod to Waterloo, with regimental tradition maintaining that so many of the Inniskillings' officers had been killed or wounded by the close of that engagement that the unit was commanded by its NCOs instead. See British Forces News, 'Royal Irish Regiment receive campaign medals as they celebrate Waterloo Day 20.06.11'

(http://www.youtube.com/watch?v=Je13KvOS-Dk) (2 Aug. 2011). The Irish battalion is also one of very few 
individual British units commemorated on the battlefield of Waterloo itself. A stone memorial erected in 1990 marks the position it held during the battle.

9517 June 1815 was marked by appalling weather which left most combatants thoroughly soaked and muddy; an unwelcome development noted in nearly all primary testimony from the Waterloo campaign. Surgeon John Haddy James of the British $1^{\text {st }}$ Life Guards, for example, observed that: 'the ground was a quagmire and if any man took a fall he rose with a coat of mud from head to foot'. See Haddy James, Surgeon James's Journal, ed. Jane Vansittart (London, 1964), p. 26.

${ }^{96}$ National Army Museum [hereafter NAM] MS 1978-05-24, letter from Lieutenant Standish O'Grady to his father, $1^{\text {st }}$ Viscount Guillamore, July 1815.

${ }^{97}$ Mike Chappell, Wellington's Peninsula regiments (1): the Irish (Oxford, 2003), p. 11.

${ }^{98}$ See letter from Lieutenant Colonel Henry Murray in H.T. Siborne, The Waterloo letters: accounts of the battle by British officers for its foremost historian (London, 2009), pp 177-84.

99 Ibid.

${ }^{100}$ Quoted in H.T. Siborne, The Waterloo letters: accounts of the battle by British officers for its foremost historian (London, 2009), p. 70.

${ }^{101}$ H.T. Siborne, The Waterloo letters: accounts of the battle by British officers for its foremost historian (London, 2009), p. 91.

102 Cavalié Mercer, Journal of the Waterloo campaign (2 vols, London, 1870), i, p. 364.

${ }^{103}$ See, for example, William Siborne, History of the war in France and Belgium in 1815 (London, 1848), p. 271.

Some accounts have additionally suggested that Ponsonby and his companion were initially taken prisoner, but were then murdered by their French captors who feared that British cavalry nearby might carry out a rescue. A specific French cavalryman named Urban, variously described as either an officer or NCO, has occasionally been named as Ponsonby's killer. See, for example, Henri Houssaye, 1815 Waterloo (London, 1900), p. 199. Ponsonby's death would later be recreated on the cinema screen in Russian director Sergei Bondarchuk's epic 1970 dramatization of the campaign, Waterloo. English actor Michael Wilding played the Irish general. Ponsonby's remains were recovered on the day after Waterloo and eventually buried in Kensington, London. See Gentleman's Magazine, Ixxxv (Jan.-Jun. 1815), p. 644.

${ }^{104}$ H.T. Siborne, The Waterloo letters: accounts of the battle by British officers for its foremost historian (London, 2009), p. 71.

105 Mark Adkin, The Waterloo companion: the complete guide to history's most famous land battle (London, 2001), p. 44.

106 See, for example, Freeman's Journal, 26 Jun. 1815

107 NA UK WO 97/55/27 (discharge papers, James Graham, $2^{\text {nd }}$ Foot Guards; $12^{\text {th }}$ Light Dragoons 1812-30). Graham has frequently been described in secondary sources as being a sergeant at Waterloo, but his entry on his battalion's Waterloo medal roll, drafted soon after the campaign, lists him as a corporal. See Christopher Buckland, The Waterloo Medal Roll (Dallington, 2001), p.148.

108 See, for example, William Siborne, History of the war in France and Belgium in 1815 (London, 1848), p. 382; as well as Edward Cotton, $A$ voice from Waterloo (London, 1877), pp 50-1. It is not definitively clear whether or not these latter two incidents actually took place, or if they happened as described in secondary sources. Graham himself does not appear to have left any first-hand account of the action.

${ }^{109}$ William Siborne, History of the war in France and Belgium in 1815 (London, 1848), p. 260. Unfortunately for Siborne and his co-recipient, Norcross became bankrupt with two years, ceasing the pension.

${ }^{110}$ Although not on public display, the portrait (catalogue reference 2611) could be viewed by appointment in July 2011.

${ }^{111}$ See, for example, Annual Register (1845), p. 271. Graham also remains the subject of colourful commemoration within the contemporary Coldstream Guards. Every December, the soldiers of the British regiment mark the successful closure of the northern gate at Hougoumont with a chaotic celebration known as 'hanging the brick'. Senior NCOs of the regiment take custody of a brick supposedly from Hougoumont and challenge other ranks to 'capture' the trophy back. As recently as 2004, a new accommodation block for soldiers of the Coldstream Guards in Aldershot, Hampshire, was named after the Irishman. See 'Sergeants' mess - customs and traditions' (http://www.shinycapstar.com/sergeantsmess.htm\#_ftn2) (4 Aug. 2011). On his death, Graham was buried in the soldiers' cemetery of the Royal Hospital Kilmainham. Regrettably, however, his grave is no longer marked as a result of road-widening carried out by Dublin City Council in the early 1990s; as confirmed during a visit to the site in July 2011.

112 Alessandro Barbero, The battle: a history of the battle of Waterloo (London, 2005), p. 193.

113 NAM MS 2002-01-254, letter from Captain Edward Kelly to Maria Louisa Kelly, July

114 Ibid.

${ }^{115}$ Charles Dalton, The Waterloo roll call (London, 1904), p. 94.

116 John Keegan has suggested that Portarlington departed to Brussels 'probably to enjoy himself'. See John Keegan, The face of battle: a study of Agincourt, Waterloo and the Somme (London, 1976), p. 190. An account provided by a brother officer of the Irishman, however, claimed that Portarlington had travelled to the rear on 
medical advice, as he had been taken severely ill. Yet another version of events pinned the blame on Portarlington's servant, for having neglected to wake his master in time on the morning of Waterloo. See Gentleman's Magazine, xxv (Jan.-Jun. 1846), pp 201-2.

117 Despite weighty patronage in the form of a friendship with Britain's Prince Regent, as well as a subsequent pathetic attempt to reinvent himself by purchasing a commission as a lowly ensign, Portarlington was never able to escape the suggestion that he had acted dishonourably at Waterloo. The Irishman is noted to have died dissolute in a London boarding house in 1845. See Gentleman's Magazine, xxv (Jan.-Jun. 1846), pp 201-2.

${ }^{118}$ Edward Costello, The adventures of a soldier (London, 1852), p. 190.

${ }^{119}$ Harry Ross-Lewin, With "The Thirty-Second" in the Peninsular and other campaigns, ed. John Wardell (Dublin, 1904), p. 266.

${ }^{120}$ Mark Adkin, The Waterloo companion: the complete guide to history's most famous land battle, (London, 2001), p. 121.

${ }^{121}$ Richard Holmes, Redcoat: the British Soldier in the age of horse and musket (London, 2002), p. 252. Mark Adkin, The Waterloo companion: the complete guide to history's most famous land battle (London, 2001), p. 121.

122 H.T. Siborne, The Waterloo letters: accounts of the battle by British officers for its foremost historian (London, 2009), p. 330. See also Charles Dalton, The Waterloo roll call (London, 1904), p.

36. Regimentally an officer of the $73^{\text {rd }}$ Highlanders, Kelly served on the staff during the campaign as an assistant quartermaster-general, but took over command of the $1^{\text {st }}$ Battalion of the $73^{\text {rd }}$ at Waterloo when its commander was wounded.

${ }^{123}$ Quoted in George Clayton Swiney, Historical records of the $32^{\text {nd }}$ (Cornwall) Light Infantry, now the $1^{\text {st }}$ Battalion, Duke of Cornwall's L.I., from the formation of the regiment in 1702 down to 1893 (London, 1893), p. 116.

${ }^{124}$ Quoted in Raymond Henry Raymond Smythies, Historical records of the $40^{\text {th }}$ ( ${ }^{\text {nd }}$ Somersetshire) Regiment, now

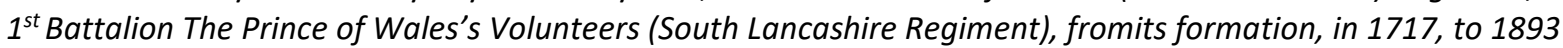
(Devonport, 1894), p. 187.

${ }^{125}$ Cavalié Mercer, Journal of the Waterloo campaign (2 vols, London, 1870), i, p. 341.

${ }^{126}$ See, for example, Mark Adkin, The Waterloo companion: the complete guide to history's most famous land battle (London, 2001), pp 312-6.

127 Staffordshire Record Office MS D3259/14/22/4C, letter, undated, from Samuel Rogers to Henrietta, Lady Bessborough; describing the account given to Rogers by her son, Lieutenant Colonel Frederick Ponsonby, of his experiences at the battle of Waterloo. See also Ben Harris McClary, 'Samuel Rogers' historic war story: a letter for Lady Bessborough', in Huntington Library Quarterly, xliv, no. 3 (summer 1981), pp 223-5.

${ }^{128}$ E.S. Jackson, The Inniskilling Dragoons: the records of an old heavy cavalry regiment (London, 1909), p. 143. See also Charles Dalton, The Waterloo roll call (London, 1904), p. 269; as well as NA (Kew) WO 97/91/25, service documents, Matthew Marshall, $6^{\text {th }}$ Dragoons 1794-1819.

${ }^{129}$ Staffordshire Record Office MS D3259/14/22/4C, letter, undated, from Samuel Rodgers to Henrietta, Lady Bessborough; describing the account given to Rodgers by her son, Lieutenant Colonel Frederick Ponsonby, of his experiences at the battle of Waterloo.

${ }^{130}$ NA (Kew) WO 25/366, description book, 32 ${ }^{\text {nd }}$ Foot $1815-26$.

131 Ibid.

132 For an authoritative account of the creation of Wellington's despatch and its journey from Belgium to the British Isles in June 1815, see Reginald Colby, The Waterloo despatch (London, 1965).

${ }^{133}$ Freeman's Journal, 26 Jun. 1815.

${ }^{134}$ Thom's Irish almanac and official directory for the year 1852 (Dublin, 1852), p. 9. See also Irish Times, 3 Jan. 1901.

135 Irish Times, 29 Oct. 1910

${ }^{136}$ See Thomas D. Veve, 'Wellington and the Army of Occupation in France, 1815-1818', in International History Review, xi, no. 1 (Feb. 1989), pp 98-108.

${ }^{137}$ Harry Ross-Lewin, With "The Thirty-Second" in the Peninsular and other campaigns, ed. John Wardell (Dublin, 1904), p. 323.

138 NAM MS 1978-05-24, letter from Lieutenant Standish O'Grady to his father, $1^{\text {st }}$ Viscount Guillamore, July 1815.

${ }^{139}$ Freeman's Journal, 16 Aug. 1815.

140 Geoffrey Wooten, Waterloo 1815: birth of modern Europe (Oxford, 1999), p. 89. Touring the area as early as July 1815, Scottish traveler James Simpson recorded being offered 'relicks [sic] of the field' for sale by enterprising Belgian peasants: '... particularly the eagles which the French soldiers wore as cap plates. A few cuirasses, both the back and breast pieces, were likewise held up to us; as well as sabres, bayonets and other spoils'. See James Simpson, A visit to Flanders in July, 1815

(Edinburgh, 1816), p. 56

${ }^{141}$ Irish Times, 20 Jun. 1865. As late as the beginning of the twentieth century, Irish battlefield tourists of this sort might still encounter the occasional grisly relic of their country's involvement in the campaign. In July 1909, the Irish Times reported the unearthing at Waterloo three years earlier of the remains of Lieutenant Michael McCluskey; an officer of the $6^{\text {th }}$ Dragoons who had been killed during the charge of the British heavy cavalry on 18 
June 1815. See Irish Times, 9 Jul. 1909; and E.S. Jackson, The Inniskilling Dragoons: the records of an old heavy cavalry regiment (London, 1909), p. 142.

142 Freeman's Journal, 9 Dec. 1818.

143 See Thom's Irish almanac and directory for the year 1850 (Dublin, 1850).

${ }^{144}$ Although Wellington has tended, almost inevitably, to dominate memorialization of this sort, other native Waterloo veterans are also commemorated in Ireland, albeit in a less prominent manner. Major George O'Malley, for example, who assumed command of the $2^{\text {nd }}$ Battalion of the $44^{\text {th }}$ Foot when fellow Irishman Lieutenant Colonel John Millet Hamerton was injured during the campaign, is commemorated by a statue in Castlebar in his home county, Mayo. Similarly, a plaque to James Graham was unveiled at the Royal Hospital Kilmainham in March 1906. Uncertainty about the institution's future after southern Irish independence in 1922 led to the memorial being moved to St Tiernach's Church of Ireland church in Graham's native Clones, County Monaghan, where it remains to the present. See Irish Times, 17 Mar. 1906; and 22 Sep. 1928.

${ }^{145}$ Although these panels are sometimes described as being cast from the metal of French guns captured during the Waterloo campaign, there seems to be little evidence to confirm this. A 1952 article in the Dublin Historical Review suggests instead that the metal used came from 'cannon captured from an enemy - any enemy - at any time or place'. See P.F. Garnett, 'The Wellington Testimonial', in Dublin Historical Review, xiii, no. 2 (Jun.-Aug. 1952), pp 48-61.

146 George Newenham Wright, An historical guide to ancient and modern Dublin (London, 1821), p. 267.

147 See, for example, Irish Times, 11 July 1891.

${ }^{148}$ Edmund Lenthal Swifte, Waterloo, and other poems (London, 1815), p. 14.

${ }^{149}$ Anonymous, The day of Waterloo: a poem. With notes, illustrating the principal events of that ever memorable battle (Dublin, 1817).

${ }^{150}$ Anonymous, $A$ volume containing 10 song books, printed in Monaghan (Monaghan, 1822), p. 3.

${ }^{151}$ Anonymous, The battle of Waterloo, a grand military melo-drama, in three acts... as performed at the TheatreRoyal, Hawkins Street [ published script of play] (Dublin, 1825).

152 Martin Aaron, ' $2^{\text {nd }}$ Battalion 69 $9^{\text {th }}$ (South Lincolnshire) Foot during the Waterloo Campaign' (http://www.napoleon-series.org/military/organization/Britain/Infantry/c_2-69Waterloo.html\#_ftn2) (14

Aug. 2011).

153 To better contextualise these figures, it should be explained that during this period there were twelve pence (d.) to a shilling (s.), and twenty shillings to a pound (f). The nominal $1 \mathrm{~s}$. that a British foot soldier might expect to earn a day was in practice considerably less once deductions for items like food and clothing were made - around $6 d$. per day might be a more realistic figure. $£ 2$ prize money for the Waterloo campaign represented for an infantry private, then, well over a month's pay, if not more. For a fuller examination of the perhaps complicated issue of contemporary military pay and currency, see Richard Holmes, Redcoat: the British soldier in the age of horse and musket (London, 2002), pp 20-3.

154 J. Harris Gibson, British military and naval medals and decorations (London, 1880), p. 138.

155 Edward Costello, The adventures of a soldier (London, 1852), p. 201.

${ }^{156}$ The medal was not without some wider controversy. For many Irish soldiers in the British army who had participated in other campaigns of the wider Napoleonic period, but who were not at Waterloo, the award became a source of profound disgruntlement. These men resented - not altogether unreasonably

- the fact that their service in perhaps a score of separate battles had gone unrecognised; while some of their military peers who had been under fire at one or two engagements during the Hundred Days qualified for decoration. Writing years later, Irish Peninsular War veteran Captain William Grattan complained with evident bitterness about the manner in which: "Waterloo" should be banded about on the breasts of his [the Duke of Wellington's] hundred thousand [sic] soldiers, more than the half of whom had never seen a shot fired before that day; and many of whom were not only not in the battle, but knew nothing about it for a day afterwards; yet all these men - absentees included - got a medal!'. See William Grattan, Adventures with the Connaught Rangers ( 2 vols, London, 1847), ii, pp 301-2. The issue would not be resolved until the Military General Service Medal was instituted in 1847 to retrospectively recognise campaign service from 1793 to 1814 .

157 NA (Kew) WO 97/817/29, service documents, Richard Chambers, 69 ${ }^{\text {th }}$ Foot $1806-27$.

158 Sudbury Post, 3 Sep. 1845.

159 Ibid.

${ }^{160}$ E.S.E. Childers and Robert Stewart, The story of the Royal Hospital, Kilmainham (London, 1921), pp 69-70. See also Irish Times, 16 Dec. 1878. In July 2011, Hall's Waterloo Medal remained on display at the former Royal Hospital Kilmainham, now the site of the Irish Museum of Modern Art.

${ }^{161}$ NA (Kew) WO 97/658/115, service documents, Patrick Molloy, 52 ${ }^{\text {nd }}$ Foot $1806-23$. No relation to author. 162 Ibid

163 NA (Kew) WO 97/234/20, service documents, Robert O'Hara, $1^{\text {st }}$ Foot 1807-26.

${ }^{164}$ Edward Costello, The adventures of a soldier (London, 1852), p. 210. Costello's fortunes ultimately took a turn for the better. Having served as a volunteer under fellow Irish Waterloo veteran George de Lacy Evans in Spain during the First Carlist War, he eventually became a warden at the Tower of London. 
165 Anonymous, 'A Waterloo veteran' in Irish Sword, vii, no. 26 (1965), p.76.

166 Irish Times, 16 Sep. 1884

167 E.S.E. Childers and Robert Stewart, The story of the Royal Hospital Kilmainham (London, 1921),

p.70. See also NA (Kew) WO 97/655/119 service documents, Robert Freeman, 52 ${ }^{\text {nd }}$ Foot 1806-17; and WO

97/655/120 service documents, Thomas Freeman, 52 ${ }^{\text {nd }}$ Foot 1806-17.

${ }^{168}$ E.S.E. Childers and Robert Stewart, The story of the Royal Hospital Kilmainham (London, 1921), pp 35-6.

169 David Murphy, Ireland and the Crimean war (Dublin, 2002), pp 26-7. The British Legion was a volunteer force which intervened in this civil war, with the tacit permission of the British government, on the side of Queen Cristina and the Spanish liberal faction. Many Irish ex-soldiers served with the force in Spain, including a number of Waterloo veterans like Edward Costello and Maurice Shea.

$170 \mathrm{Ibid}$. For a full assessment of the lengthy military career of this colourful Irishman, which prior to Waterloo had also included service in the Peninsular War and in North America during the War of 1812, see Edward M. Spiers, Radical general: Sir George de Lacy Evans, 1787-1870 (Manchester, 1983).

${ }^{171}$ Charles Dalton, The Waterloo roll call (London, 1904), pp 169-71.

172 See, for example, Francis Sheppard, London 1808-1870: the infernal wen (Berkeley, 1971), pp 37-9.

${ }^{173}$ Irish Times, 26 Dec. 1891. Confoundingly for the anti-tobacco lobby of the late nineteenth century, Gibson was noted in contemporary newspaper reports as having been a dedicated pipe-smoker from his youth until near his death. See also Charles Dalton, The Waterloo roll call (London, 1904), p. 277

${ }^{174}$ NA (Kew) WO 97/856/4, service documents, Maurice Shea, $73^{\text {rd }}$ Foot $1813-22$. Although some secondary sources have erroneously described Shea as Scottish, perhaps owing to the regiment he served in, his discharge papers make his Irish background clear. Similarly, his first name is occasionally incorrectly referenced as 'Morris' 175 Ibid.

${ }^{176}$ See, for example, Charles Dalton, The Waterloo roll call (London, 1904), p. 265.

177 David Murphy, Ireland and the Crimean war (Dublin, 2002), pp 230-1. 